\title{
GUARDA COMPARTILHADA NO BRASIL E EM PORTUGAL
}

por

MARIA BEATRIZ PEREIRA DA CUNHA RAMOS

Monografia apresentada ao Departamento de Direito da Pontificia Universidade Católica do Rio de Janeiro (PUC-Rio) para a obtenção do Título de Bacharel em Direito.

Orientador(a): Bruno Vaz de Carvalho 


\section{Agradecimentos}

Agradeço primeiramente à Deus, por ter me dado uma segunda chance.

À PUC-Rio que é uma instituição extremamente católica, humanista e solidária com os mais necessitados.

Ao corpo docente, por tanta generosidade e sabedoria.

Aos amigos e parentes que nunca me deixaram nas horas difíceis.

A professora Flavia e Dra. Luciana, do SPA que estiveram ao meu lado, este tempo todo. Aos meus pais, pela paciência, amor e carinho.

E finalmente, ao meu filho, fonte de eterno amor e aprendizado. 


\section{Resumo}

A presente monografia tem como objetivo realizar um estudo sobre a Guarda Compartilhada diante da Lei 11.698/08 no Brasil e em Portugal, com ela avaliarmos se atende efetivamente ao melhor interesse do menor. Procuramos avaliar se a Guarda Compartilhada com o advento do divórcio, e a consequente ruptura conjugal é o melhor instituto para manter o pleno desenvolvimento do menor, preservando seus direitos fundamentais. Para desenvolver o tema voltamos a nossas origens no patriarcado Romano, e sua influência no nosso direito. Para se discutir a guarda, temos que primeiramente entender o conceito da autoridade parental e sua evolução na nossa história e suas consequências na estrutura da família. A guarda vai se modificando com o passar do tempo, acompanhando as mudanças sociais, o papel dos pais também muda, hoje temos um pai participativo nos cuidados diários dos filhos, e uma mãe ativa no mercado de trabalho. Quanto a guarda em Portugal, observamos que está só é utilizada quando há um acordo favorável a guarda compartilhada. Já no nosso país temos uma aplicação diferente, na qual a falta de acordo enseja a aplicação da guarda compartilhada pelo juiz.

\section{Palavras-chave}

Autoridade Parental; Guarda Compartilhada; Melhor interesse do menor. 


\section{Sumário}

PARTE I - AS RELAÇÕES PARENTAIS

1 Autoridade parental $\quad 7$

1.1 Conceito de família $\quad 7$

1.2 Antecedentes históricos 8

1.3 Evolução do pátrio poder no direito brasileiro 9

1.4 Dever de assistir, criar e educar os filhos menores, no poder parental 13

PARTE II - EVOLUÇÃO E TIPOS DE GUARDA NO BRASIL 15

2.1 Conceito 15

$\begin{array}{ll}2.2 \mathrm{O} \text { instituto da guarda na legislação brasileira } & 16\end{array}$

$\begin{array}{lr}2.3 \text { Critérios determinantes da guarda } & 19\end{array}$

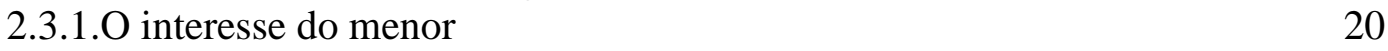

2.3.2. Idade e sexo 22

2.3.3 A opinião do menor 23

2.3.4 Comportamento dos pais 24

2.4 Tipos mais comuns de Guarda $\quad 25$

2.4.1 Guarda única 25

2.4.2 Guarda Unilateral 26

$\begin{array}{ll}2.4 .3 \text { Guarda alternada } & 27\end{array}$

2.4.4 Nidação ou aninhamento 28

2.4.5 Guarda por terceiros 28

2.5 Guarda compartilhada $\quad 29$

$\begin{array}{ll}2.5 .1 \text { Origem } & 29\end{array}$

2.5.2 Conceito 30

2.5.3 A Guarda compartilhada no direito brasileiro 31

2.5.4 Vantagens e desvantagens do modelo compartilhado 32

2.5.5 A evolução da guarda compartilhada no Brasil 34

2.5.6 Jurisprudência em relação a guarda compartilhada 34

2.5.7 Questões que põem em polos divergentes a guarda compartilhada 35

2.5.8 A mediação na guarda compartilhada 36

PARTE III EVOLUÇÃO DA GUARDA EM PORTUGAL 39

3.1 Critério legal $\quad 39$

$\begin{array}{ll}3.2 \text { O controle judicial nos acordos de guarda } & 40\end{array}$

3.3. A mediação familiar 41

3.4. O interesse do menor 43

3.5. A preferência maternal para a criança de tenra idade 45

PARTE IV- O EXERCÍCIO DO PODER PATERNAL E MODELOS DE GUARDA 48

4.1 O modelo de guarda única 48

4.1.2 Críticas a guarda única 49

4.2 A guarda conjunta 49

4.2.1 Origens e razões de seu surgimento 49

4.2.2. Modelos na Lei da Guarda Conjunta 52

4.3 O exercício do poder paternal na Legislação Civil 54

4.4 Pressupostos do exercício conjunto do poder paternal $\quad 57$ 
4.5 Vantagens e inconvenientes do exercício conjunto do poder paternal

5 CONCLUSÃO

6 BIBLIOGRAFIA 


\section{Abreviaturas e Siglas}

CC

CRFB

ECA

Inc.

Inciso
Código Civil

Constituição da República Federativa do Brasil

Estatuto da criança e do adolescente 


\section{PARTE I - AS RELAÇÕES PARENTAIS}

\section{Autoridade parental}

\subsection{Conceito de família}

O conceito da família acompanha a história, ou seja, altera-se através do tempo, e também sua definição se modifica determinada pelas razões de sua constituição. Os motivos podem ser vários: econômicos, sociais, políticos, afetivos ou, mesmo, a preservação de tradições culturais. Enfim a cada momento temos uma característica predominante, eleita culturalmente. ${ }^{1}$

A família tem sua própria dinâmica e quando sofre mudanças, afetada por processos sejam sociais, econômicos ou políticos, acaba gerando mudanças em outras áreas como na jurídica. É no seio da família que a criança se desenvolve, através da relação íntima com os pais, familiares e vizinhos.

Segundo Ana Carolina Brochado Teixeira, é no interior familiar que se reproduz a primeira organização social, onde se aprende a respeitar o próximo, ser integro e se iniciam todas as regras de convivência ${ }^{1}$. É nesse âmbito privado, nas quais, a criança trava suas primeiras experiências que serão posteriormente repetidas na vida pública, de coexistência, de cidadania, e de conflitos.

Torna-se assim a família um lugar especial onde surgem os conflitos que futuramente serão realizados no confronte entre o público e o privado,

\footnotetext{
1 TEIXEIRA, Ana Carolina Brochado. Família, guarda e autoridade parental. São Paulo.
} RENOVAR, 2005, p.12. 
sendo que a organização familiar varia com o contexto da época e suas respectivas gerações.

Sendo assim, é necessário se adequar a família ao seu contexto histórico com os valores de época, para que se possa contextualizá-la e a partir dela entender o Direito que foi construído.

\subsection{Antecedentes históricos}

A doutrina considera o direito romano como ponto inicial para o estudo evolutivo do poder familiar. As características especiais da instituição romana vieram a ser a sua base nas legislações modernas. ${ }^{2}$

No direito romano, o pátrio poder era considerado como um poder semelhante ao da propriedade, exercido pelo varão da família sobre todas as coisas e componentes do grupo familiar, incluindo esposa, filhos, escravos. O pátrio poder era um patriarcado absoluto, sem limites e eterno, sem exemplo em outros povos. ${ }^{3}$

Diante dessa concepção patriarcal era necessária uma conduta monogâmica, principalmente da mulher, e segundo Friederich Engels daí surgiu a monogamia. $\mathrm{O}$ pater famílias tinha o direito de expor ou matar o filho, de vendê-lo, de abandoná-lo e até de entrega-lo à vítima de dano causado por seu dependente, era o triunfo da propriedade privada com suas novas condiçõos econômicas.

Esses poderes extremos foram abrandados com a Lei das XII Tábuas, onde foram limitados a três a venda que o pai podia efetuar ao filho, dentre

\footnotetext{
${ }^{2}$ GRISARD FILHO, Waldyr. Guarda Compartilhada: um novo modelo de responsabilidade parental. Rio de Janeiro: Editora Revista do Tribunal, 2013, p.35.

${ }^{3}$ GAIO (I,55) afirma que, com semelhantes características, o pátrio poder só existia entre os gálatas; Apud AIAS, José. Manual de derecho romano. [S.1.: s.n.], 20??. p.191 j.
} 
outras. ${ }^{4}$ Já no período sob Justiniano o controle dos pais felizmente reduziuse ao simples direito de correção e também aboliu o noxae datio. ${ }^{5}$

Enfim, o direito Romano visava garantir o direito do pai em detrimento de qualquer membro da família, inclusive em prejuízo do filho. Ele era o membro mais importante da estrutura familiar e, por isso, todos deveriam servi-lo irrestritamente.

Já na Idade Média, segundo Carlos Alberto Bittar Filho ocorreu um conflito entre os sistemas organizadores da família, prevalecendo no direito escrito a orientação romana, na forma da legislação justiniana. Na tradição romana predominava o interesse do pai em detrimento do filho e lhe atribuía um poder perpétuo sobre os seus descendentes.

Nos estados de direito costumeiro, o direito germânico se inspirava mais no interesse do filho do que do pai. ${ }^{6}$ Concebendo o poder familiar como um direito e um dever dos pais orientando e protegendo seus filhos. Está orientação foi o gérmen da doutrina de proteção integral, perfilhado atualmente na nossa legislação pátria através do Estatuto da Criança e do Adolescente (ECA, Lei 8.069).

\subsection{Evolução do pátrio poder no direito brasileiro}

A influência da família romana foi dominante, em nossas primeiras legislações pelo fato de termos sido colonizados pelos portugueses, e estes seguirem o direito romano, através dele se percebe o modelo da arquitetura

\footnotetext{
${ }^{4}$ Se o pai vendeu o filho três vezes, que esse filho não recaia mais sob o poder paterno", dando-se emancipação. Texto conforme fragmento reconstituído por J. Godofrey. In: MEIRA, S.A.B. A lei das XII Tábuas, - fonte do Direito Público e Privado. $2^{\mathrm{a}}$ ed. Rio de Janeiro: Forense, 1961, p.169. ${ }^{5}$ ROCHA, J.V.C.B. O Pátrio Poder: estudo teórico-pratico, Rio de Janeiro: Tupã, 1960, p.21-23.

${ }^{6}$ BITTAR FILHO, Carlos Alberto. Pátrio Poder: regime jurídico pauta. Revista dos Tribunais, v. 676, 1992, p.79-84.
} 
familiar romana na família e no Direito brasileiro, inclusive sobre as relações parentais, principalmente no século XIX e grande parte do século XX. No Brasil o pátrio poder continuou sendo perpétuo por um longo período. ${ }^{7}$

Além de que a influência romana no poder familiar encontrou guarida nas Ordenações do Reino, e, assim foi translada para o Brasil pela lei de 20 de outubro de 1823, Lafayette Rodrigues Pereira, em Direitos de família, esclarecia:

Entre nós, prevalece ainda acerca deste grave assumpto a antiga legislação portuguesa que não é senão a reprodução do Direito Romano, no estado em que o deixara o imperador Justiniano, com as modificações do tempo e os costumes lhe foram fazendo ${ }^{8}$

Existem diferentes posições doutrinárias sobre esse instituto. Segundo Lafayette Rodrigues Pereira, em Direitos de família, escrito em tempos prérepublicanos, propõe o seguinte conceito: “O pátrio poder é o todo que resulta do conjunto dos diversos direitos que a lei concebe ao pai sobre a pessoa e bens do filho e famílias" (grifos nossos). ${ }^{9}$

No mesmo sentido, Clóvis Beviláqua conceitua o instituto como: “o complexo de direitos que a lei confere ao pai, sobre a pessoa e os bens dos filhos". ${ }^{10}$ A mulher desquitada era marginalizada pela sociedade burguesa conservadora. Mesmo após a criação da Lei do Divórcio, não se vislumbrava o melhor interesse do menor, questionava-se apenas a postura dos genitores, e a guarda privilegiava o cônjuge inocente (LD 10): os filhos menores ficavam com o cônjuge que a ela não haviam dado causa. No entanto a própria lei permitia abrandamentos. Havendo motivos graves, a bem dos filhos, era facultado ao juiz decidir diversamente (LD13). ${ }^{11}$

\footnotetext{
${ }^{7}$ PEREIRA, Lafayette. Direitos de família. Rio de Janeiro: Virgílio Maia, 1918, p.234.

${ }^{8}$ Idid.

${ }^{9}$ BEVILÁQUA, Clóvis. Código Civil dos Estados Unidos do Brasil Comentado. v.2 Rio de Janeiro: Francisco Alves, 1937, p. 279.

${ }^{10}$ GRISARD FILHO, Waldir. Guarda Compartilhada., p.32.

11 DIAS, Maria Berenice. Manual de Direito das Famílias. 8 ed. Rio de Janeiro: Revista dos Tribunais, 2011, p. 439.
} 
Com a nova Constituição Federal de 1988, tivemos avanços significativos em diversas áreas, ao consagrar a Carta no seu artigo $2265^{\circ} \mathrm{o}$ princípio da igualdade que assegura ao homem e à mulher os mesmos direitos e deveres referentes à sociedade conjugal. Este dispositivo deu início a um processo de extinção de discriminações e preconceitos, produzindo reflexos extremamente positivos na sociedade conjugal familiar.

Da mesma forma, o ECA (Estatuto da Criança e do Adolescente -Lei 8069/90), ao dar prioridade absoluta, a crianças e adolescentes, transformando-os em sujeitos de direito, trouxe uma nova concepção, destacando os direitos fundamentais das pessoas de zero a 18 anos.

Porém há autores como Washington Barros Monteiro e Vicente Sabino Júnior, que se referem ao instituto como um conjunto de obrigações dos pais, em relação aos filhos menores e não emancipados, sem qualquer preocupação com os correlatos direitos deles. ${ }^{12}$

Como citado anteriormente com o seu artigo $226 \S 5^{\circ}$ da CRFB, acompanhou-se a evolução da sociedade trazendo uma conceituação mais ampla como um complexo de direitos e deveres, quanto à pessoa e bens dos filhos, exercidos pelos pais na mais estrita colaboração e em igualdade de condições.

Com o Estatuto da Criança e do Adolescente em seu artigo $3^{\circ}$ se delimita o poder familiar como um conjunto de faculdades encomendadas aos pais, como instituição protetora da menoridade, com o fim de lograr o pleno desenvolvimento e a formação integral dos filhos, física, mental, moral, espiritual e social. ${ }^{13}$

\footnotetext{
12 BRASIL. Lei 8069, ECA, de 13.07.1990, art.3

13 “A criança e o adolescente gozam de todos direitos fundamentais inerentes à pessoa humana, sem prejuízo da proteção integral de que trata esta lei, assegurando-se lhes, por lei ou por outros meios, todas as oportunidades e facilidades, a fim de lhes facultar o desenvolvimento físico, mental, moral, espiritual e social, em condições de liberdade e dignidade".
} 
Atualmente se desloca a concepção. Do fulcro da pessoa dos pais, para a pessoa dos filhos, não mais como objeto de direito daqueles, mas ele próprio (o menor) é um sujeito de direitos. Na primeira metade do século passado na separação, a questão principal era a inocência do cônjuge, para se entregar a guarda.

Na nossa história os filhos sempre ficaram sob os cuidados da mãe, é ela que gera a criança em seu próprio ventre, amamenta, enquanto o homem trabalhava e sustentava a casa. As meninas brincavam de boneca e casinha, reproduzindo seu futuro, e aos meninos era permitido jogar bola, brincar de luta, ou seja, trabalhar seu corpo e sua coragem para enfrentar o mundo, mas tornando-os completamente desconhecedores de como cuidar de um filho ou da casa.

A definição de guarda era unipessoal. Na maioria das vezes a criança ficava com a mãe, e ao pai era dado o regime de visita, que o impossibilitava de conviver com o dia-a-dia da criança, deixando nele um sentimento de frustação e impotência em relação a educação do filho.

Com o passar dos anos, e mudanças sociais, os pais foram se organizando em associações, e questionando esse tipo de regime de guarda, procurando uma forma mais participativa de compartilhar com a mãe os cuidados com os filhos, porém houve enorme resistência da justiça em homologar tais pedidos, sob o fundamento de inexistir previsão legal.

A jurisprudência começa a demonstrar este movimento:

Se, exempli gratia, divorciados os pais, sua filha adolescente opta, sem hesitar, por residir em companhia do pai, tendo este e a mãe idênticas condições para o exercício do dever de guarda, impõe-se dar receptividade a sua opção, desde que se infira ter sido livremente manifestada. (TJMG AI n ${ }^{\circ}$ 188.593-8/00 rel. Des.Hyparco Immesi DJMG 24.04.2001).

Em 2008, com o advento da Lei 11.698, foi profundamente alterado o Código Civil, onde se e inseriu a guarda compartilhada junto a guarda 
unilateral (CC $\left.1.583 \S^{\circ} .^{\circ}\right)$, dando inclusive a preferência pelo compartilhamento, mesmo quando um dos cônjuges não concorde com ela (CC $\left.1.583 \S 2^{\circ}\right)$.

\subsection{Dever de assistir, criar e educar os filhos menores, no poder parental}

Deve-se considerar que, a criança e o adolescente são seres em desenvolvimento, e que a constituição impõe aos pais o dever de assistir, criar e educá-los onde cada fase de desenvolvimento tem suas peculiaridades e cada período deve ser acatado e compreendido pelo mundo adulto, ou seja, pela família, sociedade e pelo Estado.

O menor não deve ser visto apenas como um sujeito de direitos, mas sim como uma pessoa, merecedor de respeito de todos. Busca-se o real e melhor interesse dos filhos, que deve ser cuidado e educado para que se desenvolva com seus valores pessoais em um homem livre e do bem.

O dever de criar inicia com a sua concepção, pois tem sua gênese no início da existência da criança, e a partir daí dura até completar sua maioridade. A criança está diretamente ligada ao suprimento das necessidades biopsíquicas do menor, e que envolve a assistência atendendo suas necessidades básicas, tais como cuidados, orientação moral, apoio emocional, afeto, além do vestir, dar moradia e alimentação, além do acompanhamento físico e espiritual.

Todos esses aspectos da assistência ao menor refletiram no futuro em sua personalidade todos são importantes para seu pleno desenvolvimento, onde irá alcançar autonomia tanto pessoal como profissional.

Mas a criança não é um ser amorfo que deve ser moldado pelos pais, ela tem sua própria personalidade, e em seu crescimento revela-se um 
processo de intensa troca na qual muitas vezes educa enquanto também é educada, construindo mutuamente a dignidade dos indivíduos neste longo processo de desenvolvimento pessoal. Deve-se ouvi-lo e valorizar a sua vontade, nas situações existenciais, buscando com seus pais a realização da própria personalidade.

Os artigos $3^{\circ}$ e $53^{\circ}$ do ECA, dispõe que no dever de educar está implícito a obrigação de promover no filho um desenvolvimento pleno de todos os aspectos de sua personalidade, de modo a prepará-lo como cidadão e qualifica-lo para o trabalho, mediante uma educação formal e informal.

Ressaltamos que, o fato de os pais darem fim a conjugalidade não altera em nada seus poderes-deveres inerentes a autoridade parental, onde devem continuar assistindo, criando e educando os filhos independente de sua nova condição, inclusive a nova lei da guarda compartilhada traz essa responsabilização de ambos os pais, demonstrando que seus papeis não mudam com a separação. 


\section{PARTE II - EVOLUÇÃO E TIPOS DE GUARDA NO BRASIL}

\subsection{Conceito}

O vocábulo guarda segundo De Plácido e Silva, é derivado do antigo alemão Wargen (guarda espera), de que formou o francês Garde, é empregado em sentido genérico para exprimir proteção, observância, vigilância e administração.

Já a guarda dos filhos indica o direito e dever que compete aos pais ou a um dos cônjuges de ter em sua companhia ou de protegê-los em diversas circunstâncias indicadas na lei civil. E guarda tanto significa custódia como a proteção devida aos filhos pelos pais.

Segundo Mario Aguiar Moura, a guarda em sentido jurídico representa a convivência efetiva dos pais ou responsável com o menor, sob o mesmo teto, com o dever de assistência material, para sobrevivência física e moral, além de psíquica. ${ }^{14}$

Esta não se define por si mesma, porém através dos elementos que a asseguram. Conectada ao poder familiar pelos artigos 1.634, II do CC e 21 e 22 do ECA, com forte assento na ideia de posse, como diz o artigo $33 \S 1^{\circ}$, dessa lei especial, surge como um direito-dever natural e originário dos pais, que consiste na convivência com seus filhos e é pressuposto que possibilita o exercício de todas as funções parentais elencadas na nossa legislação pátria.

A guarda dos filhos é implicitamente conjunta, apenas se individualizando quando ocorre a separação do casal. O código Civil ao tratar

\footnotetext{
${ }^{14}$ MOURA, Mário Aguiar. Guarda de filho menor. Ajuris, n.19, p.15.
} 
da proteção dos filhos (CC 1.583 a 1.590), define duas formas de guarda, a unilateral e a compartilhada, onde atualmente se revela preferência pelo compartilhamento.

Não fica exclusivamente na esfera familiar quem permanece com os filhos em sua companhia, podendo a guarda ser deferida a outra pessoa, quando os pais põem em risco a vida do(s) filho(s). A preferência é por avós ou tios, para que a criança não perca totalmente o vínculo com a família. O importante é que haja afeto e afinidade com o menor ( $\mathrm{CC} 1.584 \S 5^{\circ}$ ).

Apesar da decisão dos genitores ser respeitada, deve ser criteriosamente analisada pelo juiz e pelo Ministério Público, sendo até necessário, em alguns casos, uma avaliação psicológica de toda família. Pois, em geral, os pais estão abalados e guardando muitas mágoas, no momento da separação.

Os filhos sofrem com tantas mudanças, e quanto mais se disciplina as visitas de uma forma extremamente rígida, sem considerar imprevistos, normais no dia-a-dia, acabam desgastando-os emocionalmente. Estes, muitas vezes, são usados pelos pais, como instrumento de vingança, e não como sujeitos de direitos, e sofrem em alguns graves casos de alienação parental.

\subsection{0 instituto da guarda na legislação brasileira}

A primeira regulamentação veio com o decreto 181, de 1980, que dizia em seu art.90:

A sentença do divórcio mandará entregar os filhos comuns e menores ao cônjuge inocente e fixará a cota com que o culpado deverá concorrer para a educação deles, assim como a contribuição do marido para sustentação da mulher, se esta for inocente e pobre.

O Código Civil de 1916 cuidava da dissolução conjugal e da proteção da pessoa dos filhos distinguindo a separação amigável da judicial e ditava em seu artigo 325 que deve se observar o que os cônjuges acordarem sobre a guarda dos filhos e no artigo 326, distinguia-se que no caso de haver culpa de um cônjuge ou de ambos pela ruptura, o sexo e a idade dos filhos. 
No caso de um cônjuge ser inocente ficaria o mesmo com os filhos menores, já no caso de ambos serem culpados, com a mãe ficariam as filhas menores e os filhos até seis anos de idade, onde após completar esta idade ficariam com o pai. Os filhos maiores de seis anos eram entregues à guarda do pai, e havendo motivo grave o juiz decidia de maneira diferente o exercício da guarda.

O Decreto lei 3.200 de 1941, pelo artigo 16 disciplinou a guarda do filho natural, determinando que ficasse com o progenitor reconhecente e, sob o poder do pai, salvo se o juiz decidisse de modo inverso preservando o melhor interesse do menor.

Em 1962 com a Lei 4.121 se promoveu alterações no desquite litigioso, mas conservou as disposições do desquite amigável em relação à guarda dos filhos. Ficou da seguinte forma:

a) havendo cônjuge inocente, com ele ficariam os filhos menores;

b) sendo ambos os cônjuges culpados, com a mãe ficariam os filhos menores, já não seria mais observada a distinção entre sexo e idades destes, salvo disposição contrária do juiz;

c) sendo verificado que não deveriam os filhos ficar sob a guarda da mãe nem do pai, estava o juiz autorizado a deferir a guarda a pessoa idônea da família de qualquer dos cônjuges, assegurando-se o direito de visita.

Em 1977 com o advento da Lei 6.515 que institui o divórcio no Brasil se regulamentava os casos de dissolução da sociedade conjugal e do casamento, combinando o princípio do desfazimento por culpa no artigo $5^{\circ}$ caput, com hipóteses de dissolução sem culpa, previstas no artigo $5^{\circ}, \S \S 1^{\circ} \mathrm{e}$ $2^{\circ}$ onde ocorreram as seguintes modificações em relação ao Código Civil:

a) na dissolução consensual (art. $\left.4^{\circ}\right)$, observa-se-á o que os cônjuges acordarem sobre a guarda dos filhos (cf.art. $9^{\circ}$ ); 
b) nas dissoluções não consensuais, o destino dos filhos menores obedecerá as peculiaridades de cada uma de suas modalidades;

b.1) artigo $5^{\circ}$, caput - os filhos ficarão com o cônjuge que a ela não deu causa (cf, artigo 10 caput);

b.2) artigo $5^{\circ} \S^{\circ}$ - os filhos ficarão com o cônjuge em cuja companhia estavam durante o tempo de ruptura da vida em comum (cf. artigo11);

b.3) artigo $5 \S 2^{\circ}$ - os filhos ficarão com o cônjuge que estiver em condição de assumir, normalmente, a responsabilidade de sua guarda e educação (cf. artigo 12).

c) na separação não consensual em que fossem por ela responsáveis ambos os cônjuges, os filhos menores independentemente de sexo e idade, ficariam com a mãe. (cf. $\operatorname{art} .10 \S 1^{\circ}$ ).

A constituição federal de 1988 em seu artigo 227 assegurou à criança, como dever, primeiro, da família, depois da sociedade e do Estado, o direito à convivência familiar e comunitária, cuja disciplina veio com o Estatuto da Criança e do Adolescente (Lei 8.069 em 1990) o diploma legal de um ramo do direito que vem para regular as relações jurídicas e institutos referentes ao menor de idade, dentre eles o artigo $33 \S 1$, a guarda, destinada a posse de fato do menor.

No Código de 2002, as regras não se alteram nos artigos 1.583 a 1.590 conservando-se o modelo vigente e preservando o maior interesse do menor, obediente ao Princípio $2^{\circ}$ da Declaração Universal do Direitos da Criança que diz:

A criança gozará proteção especial e ser-lhe-ão proporcionadas oportunidades e facilidades, por lei ou por outros meios, afim de lhe facultar o desenvolvimento físico, mental, moral, espiritual e social de forma sadia e norma e em condições de liberdade e dignidade. Na instituição das leis visando este objetivo levar-se-ão os melhores interesses da criança. (grifos nossos). 
Porém, deu-se um importante passo extinguindo o regime de perda do filho associado à culpa do cônjuge na separação e da prevalência materna na sua fixação em caso de culpa recíproca. Onde em consonância com o artigo 1.583 e ss do Código Civil o princípio que deve orientar o juiz na determinação da guarda é o da prevalência dos seus interesses.

Em nosso direito, a guarda dos filhos resulta de duas situações distintas e sujeitas a diferentes disciplinas, uma em decorrência da separação dos pais e outra que é regulada pelo Estatuto da Criança e do Adolescente.

\subsection{Critérios determinantes da guarda}

Após a separação do casal é comum existirem interesses conflitantes, em relação a guarda dos filhos, porém os direitos e deveres estabelecidos nas relações parentais são exercidos conjuntamente pelo pai e pela mãe em plena igualdade de condições.

Em geral na ruptura conjugal, a guarda dos filhos era diferenciada, pois estes não viveriam mais com ambos os pais sob um regime igualitário, porém com a nova Lei 11.698 de 2008 tornou-se ou unilateral ou na forma compartilhada. Essa é imposição legal que emerge do art.1584 do Código Civil que diz que:

A guarda unilateral ou compartilhada poderá ser: (Redação dada pela Lei no 11.698 , de 2008). I - requerida, por consenso, pelo pai e pela mãe, ou por qualquer deles, em ação autônoma de separação, de divórcio, de dissolução de união estável ou em medida cautelar; (Incluído pela Lei n 11.698, de 2008).

II - decretada pelo juiz, em atenção a necessidades específicas do filho, ou em razão da distribuição de tempo necessário ao convívio deste com o pai e com a mãe. (decretada a separação judicial ou o divórcio, sem que haja entre as partes acordo quanto à guarda dos filhos, será ela atribuída a quem revelar melhores condições para exercê-la.

Nesse aspecto vê-se uma grande mudança onde não se privilegia os pais pelo sexo, e sim o melhor interesse do bem estar do menor onde o juiz em caso de controvérsia deve sobrepor o interesse do filho ao interesse dos pais. Atualmente com a Lei 13.058/2014 muda-se a redação do Código Civil, que 
em geral resultava na determinação de guarda compartilhada apenas nos casos em que há boas relações entre os pais após o fim da união.

Agora, esse tipo de decisão se estende a casos de separações conflituosas. A ideia é garantir uma divisão equilibrada do tempo de convivência com cada um dos pais, possibilitando a supervisão compartilhada dos interesses do filho. Ambos poderão participar, por exemplo, do ato que autoriza a viagem dos filhos para o exterior ou para a mudança permanente de município, evitando uma tendência de retaliações aos pais que detinham a guarda e se afastavam da moradia do não detentor.

A Lei estabelece duas situações em que a guarda compartilhada não será adotada: em caso de o juiz avaliar que um dos pais não esteja apto para cuidar do filho ou quando um deles manifeste desejo de não obter a guarda.

\subsubsection{O interesse do menor}

O objetivo da lei é o de proteger os interesses de uma forma geral e abstrata, não esquecendo que cada caso concreto tem suas peculiaridades e o juiz deve observá-las cuidadosamente sempre visando interesses materiais, morais e emocionais do menor.

O interesse do menor é buscado em seu futuro com a finalidade de protegê-lo e lograr seu desenvolvimento e sua estabilidade, apto à formação equilibrada da sua personalidade, é critério de decisão do juiz ${ }^{15}$

Esse princípio em nosso direito positivo está contido no artigo 1586 do Código Civil, abrangente e superior a todas as hipóteses dos artigos que

\footnotetext{
${ }^{15}$ No direito anglo-saxão, quando se decide sobre a guarda, o tribunal dá a maior prioridade ao best interests of child, dependente de muitos fatores, incluindo: o amor, os laços afetivos ntre o pai ou titular da guarda e a criança a habitualidade do pai ou titular da guarda de dar à criança amor e orientação; a habilidade do pai ou titular da guarda de prover a criança com comida, abrigo, vestuário e assistência médica (os chamados alimentos necessários) LEONARD, Robin; ELIAS, Stephen R. Family Law Dictionary. Apud FACHIN, L.E. Estabelecimento da filiação e paternidade presumida. Porto Alegre: Sérgio Antônio Fabris, 1992, p. 98
} 
lhe são antecedentes facultando ao juiz também dispor de maneira diversa sobre a guarda que julgar mais conveniente em casos de haver motivos graves e buscando o bem dos filhos.

Seguindo os critérios da legislação italiana, francesa, espanhola e alemã, que atribui a guarda do filho a um ou a outro dos genitores, tomou como princípio o interesse dos filhos na nossa legislação, especialmente quando se refere a "verificado que não devem permanecer", "a bem do menor", isto é, reiterando que o interesse dos filhos menores deve primar por cima de qualquer outro interesse, ou circunstância, do pai ou mãe.

Uma questão imprecisa é o que realmente significa buscar o melhor interesse do menor apesar de ser constantemente utilizada nos textos legais, jurisprudência e doutrina, mas o arbítrio do juiz se dá em cada caso concreto, sendo que não encontra nenhum modelo de pauta estereotipada nem também nenhum conceito limitado, só sendo atingido no exame prático em questão.

Segundo Eduardo de Oliveira Leite, a jurisprudência tem permitido seguir algumas tendências que buscam o desenvolvimento físico e moral da criança, a qualidade se suas relações afetivas e sua inserção no grupo social, a idade, o sexo, a irmandade, o apego ou a indiferença manifestada pela criança a um de seus pais, materiais ou morais. Enfim, todos esses elementos são caminhos que servem para o juiz descobrir o que considera ser "o melhor interesse para o menor". ${ }^{16}$

Um importante aspecto é a distinção do interesse moral do material para a determinação da guarda, pois evidentemente a criança precisa ter ao seu lado um genitor que lhe dê afeto, educação seja moral, espiritual e

${ }^{16}$ LEITE, E. O. Famílias. Jornal of Law \& The Family, v. 8, n. 2, agosto de 1994, p.197. O tema do interesse do menor recebeu especial atenção da Revista internacional Jornal of Law \&The Family, editado pela Oxford Express, dedicando todo volume 8, n.2-agosto de 1994 a seu estudo, desde diversos pontos de vista e em diferentes contextos e países. 
principalmente lhe dê equilíbrio emocional. Enquanto que o lado material não anda independente do moral.

O interesse material nunca pode ser confundido com mais aptidão pessoal para exercício da guarda, este pode sim ser convertido em alimentos. Enfim quando se trata de guarda dos filhos, o interesse do bem-estar do menor é o único critério a solucionar o problema devendo prevalecer acima do social, jurídico, psicológico ou sentimental.

O Supremo Tribunal Federal decidiu que o que prepondera é o interesse do menor e não a pretensão do pai ou da mãe, pois o seu conteúdo é o bem-estar material e emocional dos filhos, seus aspectos morais e espirituais, sua saúde corporal e intelectual, sem comprometer seu adequado desenvolvimento.

\subsubsection{Idade e sexo}

Com a revogação dos artigos a 328 do CC de 1916 pela Lei do Divórcio, e desta pelo Código Civil de 2002, essa questão foi suprimida do debate pela determinação da guarda pois, as pesquisas focavam primeira e fundamentalmente no interesse do menor independente de sexo ou idade.

Não se pode, porém, desconsiderar que nos primeiros dois anos a criança está mais vinculada a mãe, onde sua personalidade se desenvolve por instintos. Ensinam os psicólogos e psicanalistas que o bebê até os 24 meses se sente uno a mãe, da qual não se discrimina e depende física e psicologicamente de modo que a guarda deve ficar com a mãe. ${ }^{17}$

\footnotetext{
17 MARRACCINI, Eliane Michelini; MOTTA, Maria Antonieta Pisano. Guarda dos Filhos: Algumas diretrizes psicanalíticas. Revista dos Tribunais, v.716, p. 346-357.
} 


\subsubsection{A opinião do menor}

Apesar de nossa legislação Civil ter ficado silente em relação a oitiva dos filhos em caso de separação ou divórcio dos pais o Estatuto da Criança e do Adolescente (ECA) previu em diversos artigos independente de ser criança ou adolescente ocorrerão a oitiva destes como um direito de opinião e expressão, integrante da liberdade.

Na separação consensual o juiz não questiona o que foi decidido em relação a guarda dos filhos, pois entende que o interesse majoritário é o bemestar do seu filho. Porém na separação litigiosa é comum que alguns pais procurem fazer todas as vontades da criança para que esta seja considerada a preferida na oitiva para escolha da guarda.

Nesse teor é necessário que o juiz entenda a complexidade da situação avaliando ponderadamente e distinguindo aspectos como o grau de maturidade do menor e sua capacidade de ser manipulado e sofrer algum tipo de alienação parental.

Esse cuidado foi assentado pela Convenção dos Direitos da Criança em seu artigo 12:

1. Os Estados partes assegurarão à criança que estiver capacitada a formular seus próprios juízos o direito de expressar suas opiniões livremente...

2. Com o tal propósito, se proporcionará à criança, em particular, a oportunidade de ser ouvida em todo processo judicial ou administrativo que afete a mesma, quer diretamente ou por intermédio de um representante ou órgão apropriado,..

Essa tendência já ocorre no dia a dia dos tribunais, é claro nunca constrangendo a criança a escolher com qual genitor quer ficar, e sim se expressando diante do juiz, de psicólogo ou assistente social de forma adequada a sua idade. Apesar de que, não se rejeita essa hipótese em alguns casos específicos na jurisprudência. 
Favorável a oitiva do menor Eduardo de Oliveira Leite ${ }^{18}$ diz que sua contribuição deve depender de avaliação de sua capacidade de discernimento sempre que as circunstâncias exigirem, porém como elemento investigatório e não vinculante a decisão do juiz. Não se tratando de constranger o menor a prestar um depoimento sem confrontar sua avaliação com os demais elementos concorrentes.

\subsubsection{Comportamento dos pais}

É importante também que o Juiz, dentro das necessidades do menor, avalie as condições que cercam seus pais, sejam materiais (profissão, renda, habitação) ou morais (ambiente social, idoneidade, retidão de caráter).

A conduta de um dos genitores ou de ambos, quando contrária à ordem e à moral familiar, tem uma grande importância na determinação da guarda dos filhos menores. Quando se revela ao juiz condutas imorais, ilícitas ou reprováveis são situações que fazem com que se tomem decisões para limitar ao máximo as relações parentais para que a criança não seja prejudicada em seu desenvolvimento.

Para Edgard de Moura Bittencourt em seu livro Guarda de filhos diz:

os pronunciamentos judiciais sobre a guarda de menor devem atender a diversos elementos e circunstâncias, que podem ser enfeixados nos seguintes pontos: o interesse da criança, as condições e o comportamento dos pretendentes à guarda e a alterabilidade desta a qualquer tempo. ${ }^{19}$ (Grifos nossos)

Uma questão um pouco mais delicada é a homossexualidade de um ou de ambos os pais onde assumem durante o casamento e no divórcio uma nova opção sexual. Não se deve, entretanto, confundir conduta imoral com preferência sexual e seu consequente preconceito, no caso em relação a um homossexual o ministro relator do STJ alertou que "o Poder Judiciário precisa ficar atento para não transformar estas distinções em coisa julgada”,

\footnotetext{
${ }^{18}$ LEITE, E. O. Famílias., p.206.

${ }^{19}$ BITTENCOURT, E.M. Da guarda de Filhos. São Paulo: Leud, 1981, p.70-73.
} 
pois o homossexual não pode sofrer restrições, merecendo sua palavra o mesmo crédito do heterossexual. Só “assim se concretiza o princípio da igualdade, registrado na Constituição da República e no Pacto de San Jose da Costa Rica. ${ }^{20}$

\subsection{Tipos mais comuns de Guarda}

\subsubsection{Guarda única}

Embora o primeiro instituto diga respeito à guarda e em que se desdobrará, impõe-se breve referência com respeito a guarda do menor regulamentada pelo Estatuto. Em princípio e na maioria das vezes a guarda é exercida pelos pais quando vivem em comum, e chamada de guarda comum, inserida no seio da família.

A guarda única vem disciplinada nos artigos 33 e 35 da lei do ECA. Uma vez regulamentada obriga a assistência material, moral e educacional do menor, conferindo a seu(s) detentor(es) o direito de se opor a terceiros, inclusive aos pais, no artigo 33 . Visa regularizar a posse de fato $^{21}$, podendo ser deferida liminar ou incidentalmente.

A guarda prevista no Estatuto decorre do abandono e da orfandade, o Estatuto prevê duas modalidades de guarda a definitiva e a provisória. Sendo que a definitiva regulariza a posse de fato do menor, no processo de adoção. É provisória, precária, especial aquela que se dedica a atender a situações peculiares ou suprir a falta eventual dos pais ou responsáveis, fora dos casos de tutela ou adoção.

20 BRASÍLIA, STJ. 6aT.,REsp 1997/0081208-1(DF). Rel.Min. Luiz Vicente Cernichiaro, J.26.05.1998. São Paulo: Revista dos Tribunais. v. 763, p. 536-540.

${ }^{21}$ LEITE, E. O. Famílias., p.206; p.43: "Por razões mais diversas, é possível que o menor não esteja em companhia dos pais". 
É importante ressaltar que a definitividade da guarda é paradoxalmente relativa porquanto pode ser modificada a qualquer tempo, mediante ato judicial fundamentado (artigo 35), pois sua concessão não faz coisa julgada.

Outro aspecto que se deve ressaltar em relação a guarda é que diferentemente da tutela e da adoção não afeta o poder familiar, pelo que não afasta o dever material dos pais de assistência, v.g. os alimentos inclusive se o menor dela necessitar, apesar de o guardião estar obrigado a prestar assistência moral, material e educacional. ${ }^{22}$

A questão previdenciária destacada no artigo $33 \S 3^{\circ}$ inscreve que à criança ou o adolescente se confere a condição de dependente, para todos os efeitos legais, incluindo o previdenciário, porém o Dec.4.032 de 2001 retirou o menor sob guarda judicial da proteção previdenciária estatal, por outro, equiparou o enteado e o menor sob tutela a filho na Lei 9.528 de 1997, aos efeitos previdenciários.

\subsubsection{Guarda Unilateral}

Historicamente a guarda era unilateral e pertencia em sua maioria a mãe. A guarda a um só dos genitores estabelece ao que não contém a guarda o regime de visitas. A custódia unipessoal, será atribuída ao genitor que apresente melhores condições de exercê-la e, objetivamente, propicie ao filho com fulcro no art $1.583 \S 2^{\circ}$, afeto, saúde, educação e segurança.

A crítica que se faz a guarda unilateral é que ela afasta o laço de paternidade da criança com o genitor não guardião, segundo Evandro Lins

\footnotetext{
22 SILVA.J.L.M. A família Substituta no Estatuto da Criança. São Paulo: Saraiva, 1995, p.59-60, adverte que "leitura açodada do artigo 33,caput, poderia sugerir, contudo, a seguinte ilação: uma vez que o guardião se encontra obrigado, mercê do enunciado legal supracitado, a prestar alimentos ao menor cuja guarda detém, mostrar-se ia vigoroso o argumento segundo o qual os genitores estariam livres de cumprir idêntica obrigação. Afinal de contas, poder-se-ia argumentar, estando o menor sob a guarda de outrem, que os pais se eximiriam, por completo, do dever de prestar alimentos.
} 
Silva é crescente o número de pais separados e filhos, que chegam ao consultório para se submeterem a uma perícia psicológica, onde os filhos estão apresentando alguns sintomas provocados pela ausência do progenitor.

O genitor não guardião seguirá um regime de visita, que formaliza a relação, deixando um sentimento de impotência e perda em relação ao cotidiano e crescimento do filho. Isso demonstra que o genitor não guardião não deve ser afastado do que ocorre com seu filho, segundo a lei no art.1.583 $\$ 3^{\circ} \mathrm{CC}$ este deve supervisionar os seus interesses. Também lhe é concedido o direito de fiscalizar sua manutenção e educação (CC 1.589). As escolas devem informar aos pais, sua proposta pedagógica, e informar a ambos o rendimento e frequência do aluno.

Existe também a família monoparental, que ocorre quando o filho só é reconhecido por apenas um dos pais, geralmente a mãe, e fica obviamente sob a guarda de quem o reconheceu (CC 1.612). O que é muito comum nas camadas de baixa renda, que dificilmente tem acesso ao reconhecimento de paternidade pelo exame de DNA.

No artigo 1.611CC temos uma exigência totalmente inconstitucional e discriminatória, pois, determina que a criança reconhecida pela mulher casada, só poderá residir no lar do casal se houver autorização do marido. Esta lei confronta com o artigo 227 da Constituição Federal que assegura com prioridade absoluta, a criança ter direito a convivência familiar.

\subsubsection{Guarda alternada}

Nesse modelo de guarda se atribui a ambos os genitores sendo que em períodos alternados o menor mora com cada um dos pais. Dessa forma cada um dos pais num período de tempo pré-estabelecido a eles, exerce de forma exclusiva a totalidade de direitos-deveres que integram o poder parental. Esse tipo de guarda é consentida em casos excepcionais pois fere ao princípio de 
"continuidade" que pode gerar ansiedade e instabilidade emocional na criança, e não é indicado para criança em tenra idade.

\subsubsection{Nidação ou aninhamento}

Nesse caso, são os pais que revezam mudando para a casa em períodos alternados, cuidando dos menores, porém tais acordos não perduram, pois exigem uma enorme despesa para se manter três residências, uma para o pai outra para a mãe e uma terceira para que ambos convivam alternadamente com a criança.

\subsubsection{Guarda por terceiros}

Já se dispunha no art.327 do CC de 1916, revogado pela Lei do Divórcio, sobre em casos de haver motivos graves, o juiz regular a situação dos filhos, entregando-os a terceiras pessoas. No mesmo sentido o art. $16 \S 1^{\circ}$ do Dec.lei 3.200 de 1941:

Verificando que não deve o filho permanecer em poder da mãe ou do pai, deferirá o juiz a sua guarda a pessoa notadamente idônea, de preferência da família de qualquer dos genitores.

Essa possibilidade foi mantida pela Lei do divórcio em seu art.10§2 com modificação possibilitando que a criança além dos parentes pode também ser deferida a estranhos, como facultaram os arts. 13 e 15, dessa mesma Lei. No ECA, a figura do terceiro consubstancia-se na família substituta.

$\mathrm{Na}$ vigência do atual Código Civil enfatiza-se o resguardo do interesse do menor, verificando o juiz que se os filhos não devem permanecer sob a guarda do pai ou da mãe, deve-se deferir a quem tenha compatibilidade e afinidade com o menor, tendo em conta em ordem de preferência o grau de parentesco, afinidade e compatibilidade, na forma do parágrafo único do art.1.584 do CC, ampliando-se desta forma o leque de pessoas capazes de assumirem essa obrigação. 


\subsection{Guarda compartilhada}

\subsubsection{Origem}

A guarda compartilhada, com o nome joint custody teve início na Inglaterra por volta dos anos sessenta, mais precisamente descrita pelo professor Eduardo Oliveira Leite:

A manifestação inequívoca dessa possibilidade por um tribunal inglês só ocorreu em 1.964, no caso Clissold, que demarca o início de uma tendência que fará escola na jurisprudência inglesa. Em 1972, a Court d Appel da Inglaterra, na decisão Jussa x Jussa reconheceu o valor da guarda conjunta, quando os pais estão dispostos a cooperar e, em 1980 a Court d Appel da Inglaterra denunciou, rigorosamente, a teoria da concentração da autoridade parental nas mãos de um só guardião da criança. No célebre caso Dipper x Dipper, o juiz Ormrod, daquela Corte, promulgou uma sentença que, praticamente, encerrou a atribuição da guarda isolada na história jurídica inglesa. ${ }^{23}$

Na França, esta modalidade de guarda foi assimilada a partir de 1976, com o intuito de diminuir as injustiças causadas pela guarda isolada, consolidando desde então, a importância de ambos os genitores no exercício da autoridade parental. Assim, para a legislação francesa os direitos e deveres dos pais permaneciam depois do divórcio, fazendo que a guarda unilateral seja considerada uma exceção, ou seja, a regra se torna a utilização da guarda compartilhada.

Nos Estados Unidos na década de setenta repercutiram essas novas decisões e se iniciou o uso da guarda compartilhada, tentando evitar problemas comportamentais que ocorriam em filhos de pais divorciados, e rapidamente sua forma foi utilizada no país, sendo que é atualmente aplicada e desenvolvida por meio de estudos de comportamento, e é considerada como um meio, mas adequado ao pleno desenvolvimento e bem estar dos filhos.

Enfim temos hoje a guarda compartilhada como uma tendência no mundo ocidental e surge num contexto de globalização que demonstra um desgaste da guarda exclusiva e do crescente desequilíbrio que ocasiona ao

\footnotetext{
${ }^{23}$ LEITE, E. O. Famílias., p. 266.
} 
exercício dos direitos e deveres dos pais, de uma cultura igualitária que prioriza o interesse do menor e seu equilíbrio emocional.

\subsubsection{Conceito}

A guarda compartilhada assume uma importância extraordinária, na medida em que valoriza o convívio do menor com seus dois pais, pois mantém, apesar da ruptura conjugal, o exercício em comum da autoridade parental e reserva, a cada um dos pais, o direito de participar das decisões importantes que se referem à criança. ${ }^{24}$

Com o divórcio, rompe-se a dinâmica familiar, e os pais deixam de exercer conjuntamente as funções parentais. Esse processo de redefinição de encargos leva um tempo, de forma a que pais e filhos progressivamente irão se adaptando as novas regras, horários e casas.

A guarda conjunta foi a forma encontrada, para garantir ao pai que anteriormente era um mero provedor de recursos, e não detentor da guarda conforme a maioria das decisões judiciais, efetivamente ter uma corresponsabilidade parental, buscando a ampla participação deste na formação e educação do filho.

Os fundamentos da guarda compartilhada são de ordem constitucional e psicológica, visando basicamente garantir o interesse do menor. ${ }^{25}$ Significa mais prerrogativas aos pais, fazendo com que estejam presentes de forma mais intensa na vida dos filhos. Esta participação leva a pluralização das responsabilidades, estabelecendo verdadeira democratização de sentimentos.

A proposta é manter os laços de afetividade, minorando os efeitos negativos que a separação acarreta aos filhos tentando conferir aos pais o exercício da função parental de forma igualitária. Para isso, é necessária a mudança em alguns paradigmas, levando em conta a necessidade de

\footnotetext{
${ }^{24}$ Lei 11.112/05. Apud DIAS, Maria Berenice. Manual de Direito das Famílias., p. 447.

${ }^{25}$ BAPTISTA, Silvio Neves. Guarda Compartilhada. Recife: Bagaço, 2008.
} 
compartilhamento entre os genitores da responsabilidade parental e das atividades cotidianas de cuidado, afeto e normas que ela implica. ${ }^{26}$

\subsubsection{A Guarda compartilhada no direito brasileiro}

No nosso texto constitucional ao prever a absoluta igualdade entre homem e a mulher $\left(\operatorname{art} .5^{\circ}, 1\right)$ e a igualdade de direitos e deveres inerentes a sociedade conjugal a serem exercidos pelo homem e pela mulher (art. $226, \S 5^{\circ}$ ), reclama uma paternidade responsável (art. $226 \S 7^{\circ}$ ). O Estatuto da Criança e do Adolescente, dispondo sobre a proteção integral do menor $\left(\operatorname{art.} 1^{\circ}\right)$, impõe à família, à comunidade, à sociedade e ao Poder Público o dever de assegurar ao menor uma convivência familiar plena à consideração de sua condição de pessoa em desenvolvimento.

Além disso, é garantido ao menor o direito de participar da vida familiar (art. 16,V) e de ser "ser criado e educado no seio de sua família", (art. 19), submetendo-se ao poder familiar do pai e da mãe, exercido em igualdade de condições (art. 21), sendo assim, está claro que o ECA privilegia a convivência da criança com ambos os pais, sendo favorável a guarda compartilhada.

A parcialmente revogada Lei do Divórcio, em seu art.13, semelhante ao art.1.586 do atual Código Civil permitia ao juiz decidir por outro modelo de guarda: "Se houver motivos graves, poderá o juiz, em qualquer caso, a bem dos filhos, regular por maneira diferente da estabelecida nos artigos anteriores a situação deles com os pais".

\footnotetext{
${ }^{26}$ BRUNO, Denise Duarte. Direito de visita: direito de convivência. In: GROENINGA, Giselle Camara; PEREIRA, Rodrigo da Cunha (coords.). Direito de família e psicanálise. São Paulo: Imago, 2003, p. 311-324.
} 
Da mesma forma, o Decreto-Lei 3.200/1941, nos $\S \S 1^{\circ}$ e $2^{\circ}$ do art.16, de forma expressa, autoriza o juiz a resolver sobre a guarda de modo a atender o critério do melhor interesse do menor.

Quanto ao Código Civil de 2002, a alteração mais significativa foi a separação tópica entre a disciplina do exercício do poder familiar quanto à pessoa dos filhos menores e a do exercício do poder familiar quanto aos bens e aos filhos menores, que ao tempo do Código de 1916 constituíam seções de um mesmo capítulo, o relativo ao pátrio poder.

Apesar de todas as possibilidades de se realizar a guarda na forma compartilhada no direito brasileiro, este tinha pouca admissibilidade antes da Lei 11.698/2008, pois era incomum na doutrina e tímido na jurisprudência, e com frequência confundida com a guarda alternada ou com visitação livre.

Como diversos movimentos de pais e mães separados clamavam por mudanças no modelo de guarda que era preferencialmente unilateral, foi apresentado pelo então Deputado Tilden Santiago (PT-MG) o projeto de Lei 6.350/2002, com a finalidade de alterar os art. 1.583 e 1.584 do CC/2002, para decidir por acordo ou por decisão judicial, a guarda compartilhada, buscando segundo seu autor reorganizar as relações entre pais e filhos após a separação, buscando diminuir o distanciamento e o sofrimento da distância de um dos pais, que na maioria das vezes tinha o pai como o não detentor da guarda.

\subsubsection{Vantagens e desvantagens do modelo compartilhado}

Segundo as estatísticas em pleno século XXI, as mães continuam a ficar com a guarda dos filhos na maioria dos casos de divórcio, embora cresça o número de pais divorciados ou não que participam cada vez mais intensamente do cotidiano dos filhos.

Essas mudanças são observadas por Edward Teyber quando discorre sobre a perspectiva histórica da família americana dizendo: 
A urbanização e a industrialização do século XX, a entrada das mulheres no mercado de trabalho durante a Segunda Guerra e depois dela e o controle da fertilidade pela contracepção nos anos 60 contribuíram, em conjunto, para a guinada dos papéis, nas responsabilidades e nos poderes decisórios tradicionais na família. ${ }^{27}$

A escalada feminina no mercado de trabalho, seu direito à escolha individual à construção de sua própria história, para além das funções maternas, fizeram crescer, em paralelo a figura do pai afetuoso e do companheiro amoroso, profundamente envolvido com a vida diária da família e a criação dos filhos. Assim é que nos casais contemporâneos as funções parentais estão mais equilibradas, distribuídas equitativamente entre os dois genitores, que dividem e compartilham entre si os deveres da educação e da manutenção dos filhos. ${ }^{28}$

Sendo assim, tenta-se tirar o pai da função de um mero visitador quinzenal, e traz o direito da criança em viver sua rotina com ambos, seja fazendo um dever, escutando uma estória ao dormir, sendo cuidada efetivamente pelos pais de uma forma alternada.

Além da rotina, a guarda compartilhada permite que o pai participe de decisões importantes como a escola em que a criança vai estudar e quais os melhores cursos que a criança deve participar. Retirando do pai a figura de um mero visitador quinzenal, e trazendo aos filhos o direito de viver sua rotina com ambos, seja fazendo dever, escutando uma estória ao dormir, sendo cuidada efetivamente pelos pais de uma forma alternada.

É importante que os pais divorciados percebam que o emocional e o bem estar do menor dependem da ampla convivência da criança com ambos, porém o que se costuma fazer quando o divórcio não é bem elaborado, é tornar a visitação e o convívio com o filho um tormento, tentando magoar o

27 TEYBER, E. Apud GRISARD FILHO, Waldyr. Guarda Compartilhada., p.13.

${ }^{28}$ Sobre a importância da participação de pai e mãe na educação dos filhos, SAYÃO, R. Pai e mãe podem pensar diferente na educação. Folha de São Paulo, Folha equilíbrio. Suplemento, 24 de junh. 2004, p.9. 
ex-cônjuge. Esquecendo que a maior vítima dessa vingança será o próprio filho.

\subsubsection{A evolução da guarda compartilhada no Brasil}

De acordo com o IBGE no anuário estatístico brasileiro de 2007, que corresponde ao período de 1984 até 2007, se verificou que foi crescendo o número de mulheres que detiveram a guarda dos filhos (de 79\% em 1984 para $89 \%$ em 2007), enquanto o número de homens com a guarda diminuiu (de 12\% em 1984 para 6\% em 2007), e número de separações nas quais ambos os cônjuges a detiveram se manteve relativamente estável, com uma leve queda (de 3,5\% em 1984 para 3,2\% em 2007).

De 2007 para 2009, o percentual de guardas femininas caiu 1,5\% e de masculinas caiu $0,15 \%$, e as guardas conjuntas aumentaram 1,5\% (para $4,7 \%)$.

Observa-se assim que o Poder Legislativo tem buscado responsabilizar ambos os pais ao cuidado de seus filhos. Ainda assim, tem-se a ideia que a mulher é sempre a responsável em grande maioria ao cuidado e criação dos filhos, mantendo o modelo de pai provedor.

\subsubsection{Jurisprudência em relação a guarda compartilhada}

DIREITO GUARDA COMPARTILHADA. CONSENSO. NECESSIDADE. ALTERNÂNCIA DE RESIDÊNCIA DO CIVIL E PROCESSUAL CIVIL. FAMÍLIA. MENOR. POSSIBILIDADE.1. A guarda compartilhada busca a plena proteção do melhor interesse dos filhos, pois reflete, com muito mais acuidade, a realidade da organização social atual que caminha para o fim das rígidas divisões de papéis sociais definidas pelo gênero dos pais.2. A guarda compartilhada é o ideal a ser buscado no exercício do Poder Familiar entre pais separados, mesmo que demandem deles reestruturações, concessões e adequações diversas, para que seus filhos possam usufruir, durante sua formação, do ideal psicológico de duplo referencial. 3. Apesar de a separação ou do divórcio usualmente coincidirem com o ápice do distanciamento do antigo casal e com a maior evidenciação das diferenças existentes, o melhor interesse do menor, ainda assim, dita a aplicação da guarda compartilhada como regra, mesmo na hipótese de ausência de consenso. 
RESP - RECURSO ESPECIAL - 1428596 - TERCEIRA TURMA - MINISTRA NANCY ANDRIGHI - DJE - 25/06/2014 "FAMÍLIA. GUARDA COMPARTILHADA. CONSENSO. NECESSIDADE. ALTERNÂNCIA DE RESIDÊNCIA DO MENOR. POSSIBILIDADE. 1. Ausente qualquer um dos vícios assinalados no art. 535 do CPC, inviável a alegada violação de dispositivo de lei. 2. A guarda compartilhada busca a plena proteção do melhor interesse dos filhos, pois reflete, com muito mais acuidade, a realidade da organização social atual que caminha para o fim das rígidas divisões de papéis sociais definidas pelo gênero dos pais. 3. A guarda compartilhada é o ideal a ser buscado no exercício do Poder Familiar entre pais separados, mesmo que demandem deles reestruturações, concessões e adequações diversas, para que seus filhos possam usufruir, durante sua formação, do ideal psicológico de duplo referencial. 4. Apesar de a separação ou do divórcio usualmente coincidirem com o ápice do distanciamento do antigo casal e com a maior evidenciação das diferenças existentes, o melhor interesse do menor, ainda assim, dita a aplicação da guarda compartilhada como regra, mesmo na hipótese de ausência de consenso.

RESP - RECURSO ESPECIAL - 1251000 - TERCEIRA TURMA MINISTRA NANCY ANDRIGHI DJE DATA:31/08/2011 PEDIDO DE GUARDA COMPARTILHADA DE MENOR POR TIO E AVÓ PATERNOS. PEDIDO JURIDICAMENTE POSSÍVEL. SITUAÇÃO QUE MELHOR ATENDE AO INTERESSE DA CRIANÇA. SITUAÇÃO FÁTICA JÁ EXISTENTE. CONCORDÂNCIA DA CRIANÇA E SEUS GENITORES. PARECER FAVORÁVEL DO MINISTÉRIO PÚBLICO ESTADUAL. RECURSO CONHECIDO E PROVIDO. I. A peculiaridade da situação dos autos, que retrata a longa co-habitação do menor com a avó e o tio paternos, desde os quatro meses de idade, os bons cuidados àquele dispensados, e a anuência dos genitores quanto à pretensão dos recorrentes, também endossada pelo Ministério Público Estadual, é recomendável, em benefício da criança, a concessão da guarda compartilhada. II. Recurso especial conhecido e provido. RECURSO ESPECIAL - 1147138 QUARTA TURMA MINISTRO ALDIR PASSARINHO JUNIOR -DJE DATA:27/05/2010. (grifos nossos)

\subsubsection{Questões que põem em polos divergentes a guarda compartilhada}

Inicialmente os próprios juízes divergem em relação a adotar este tipo de guarda em caso de casais em litígio. Uns acreditam que dividir as questões do filho traz ainda mais conflito tornando a convivência dos pais num clima de tensão tão forte que pode refletir nas crianças indiretamente. E novamente trazer para o judiciário a solução dos impasses inconciliáveis para ex. casais que não se entendem.

Já, outro grupo, considera que a guarda compartilhada vá forçar os pais mesmo em conflito a se comunicarem para resolverem conjuntamente as questões dos filhos, o que de alguma forma é mais justo, do que tomar as decisões unilateralmente. 
Outra situação que gera conflito é a guarda compartilhada no caso de casais que tem filhos muito pequenos. Neste caso, a criança precisa segundo alguns psicólogos de um ambiente mais estável, e, por isso não seria saudável mudara constantemente de ambiente e de cuidador, uma vez que estas mudanças demandam que ela tenha uma capacidade de se adaptar mais facilmente, capacidade tal que só irá adquirir quando mais velha. (Nazareth, 1997).

\subsubsection{A mediação na guarda compartilhada}

Dispõe art. 1.584 do Código Civil que a guarda unilateral ou compartilhada, poderá ser requerida por consenso ou no inciso II por decretação do Juiz sem consenso parental em atenção as necessidades específicas do filho, ou em razão da distribuição de tempo necessário ao convívio deste com o pai e com a mãe.

Ocorre que este modelo exige compartilhamento de decisões e atitudes cotidianas em relação ao exercício dos deveres e direitos relativos ao filho em comum, além das rotinas diárias do dia a dia. Agindo em conjunto em diversas situações que são difíceis de serem realizadas por um casal recém separado que vive em discórdia, e se coloca diante de uma decisão judicial imposta pelo Juiz.

Uma tentativa de termos uma guarda compartilhada sustentável e resolver essa dificuldade de convivência entre os ex-cônjuges e trazer um consenso seria através da técnica de mediação.

A mediação tem a intenção de gerir os conflitos de uma forma amigável, onde se oferecem caminhos para solucioná-los e se pretende alcançar um acordo. Esse processo é conduzido por um terceiro neutro, que detém uma técnica para realizar a mediação entre as partes. 
A mediação pode ser um recurso a ser utilizado nas questões familiares, em especial na disputa pela guarda e especialmente na guarda compartilhada e ser inserida no $\$ 3^{\circ}$ do art.1584 do Código Civil que diz que:

Para estabelecer as atribuições do pai e da mãe e os períodos de convivência sob a guarda compartilhada, o juiz, de ofício ou a requerimento do Ministério Público, poderá basear-se em orientação técnica profissional ou de equipe multidisciplinar.

Nesse caso o mediador faria parte de uma equipe multidisciplinar, não somente nas questões atinentes à guarda compartilhada, mas também nas questões relativas à regulamentação geral do exercício do poder familiar diante do conflito parental.

A família adoece muitas vezes e não se dá conta que suas decisões rotineiras em relação ao filho envolvem mágoas, amor, ódio, ciúmes entre diversos outros sentimentos e é preciso orientação profissional para que se restabeleça o equilíbrio de emoções e consequentemente a paz nas relações jurídicas e rotineiras que surgiram no pós-divórcio.

Esse auxílio pode vir pelas mãos de profissionais da saúde (psicólogos, psiquiatras, psicanalistas) e também por advogados, assistentes sociais enfim é um procedimento mediatório, e o que se busca é a solução de conflitos que tornariam a convivência de ambos em prol da educação da criança inviável, e que prejudicaria a própria criança.

Deve-se ressaltar que a mediação nada tem a ver com uma terapia de casal, nela existem técnicas onde se realizam alguns poucos encontros ou sessões onde as partes são encaminhadas pelo judiciário ou pelos próprios advogados ou terapeutas.

A mediação ocorre numa sessão de 45 minutos onde o mediador se coloca como um condutor neutro que vai orientar o diálogo entre as partes enquanto esclarece dúvidas e regras para que flua a mediação de uma forma positiva baseada no respeito mútuo e comprometimento de ambos os pais na solução de seus conflitos. 
Se houver acordo, este será redigido e posteriormente, se necessário, será homologado pelo juiz. Enfim, a mediação é um meio eficaz na condução dos conflitos, porque a solução dos impasses é construída pelos envolvidos dentro de uma relação linear e não é imposta pelo Estado, evocando somente a responsabilidade entre as partes, trazendo assim maior chance de se manter ao longo do tempo. 


\section{PARTE III EVOLUÇÃO DA GUARDA EM PORTUGAL}

\subsection{Critério legal}

O art. 1905 do CC em consonância com os artigos 180 e 177 da OTM (Organização Tutelar de Menores) prescreve que nos casos de divórcio, separação judicial o destino dos filhos, ou seja, a escolha da pessoa a quem o menor será confiado será regulado de harmonia com o interesse do menor, incluindo o de manter uma relação de grande proximidade com o progenitor a quem não seja confiada a guarda. $\mathrm{O}$ exercício de atribuição a quem é determinada a guarda pode ser feita por acordo entre os pais ou mediante uma decisão judicial em caso de divórcio litigioso será homologado pelo tribunal $\left(\operatorname{art} .1905^{\circ} \mathrm{n} 1\right)$.

A guarda tem seu regime estabelecido no art. $1902 \mathrm{n}^{\circ} 2$ do CC, segundo o qual a guarda pode ser confiada a qualquer um dos pais, e em caso de perigo a criança esta pode ser confiada a terceiros ou a estabelecimentos de educação e assistência. Neste caso, o Ministério Público deve requerer a aplicação de medida judicial de proteção (art. 148, nº 3 , al.b) da O.T.M.

O Tribunal assume um dever de proteção dos menores, como a parte mais fraca dentro da família, e também um dever de proteção dos cônjuges, sobretudo daquele que fica com a guarda do filho e que, normalmente, é a mulher, mais desfavorecida economicamente e mais sujeita a chantagens, pois em regra, não considera diferentemente dos homens, a guarda dos filhos como uma questão negociável. ${ }^{29}$

\footnotetext{
29 SOTTOMAYOR, Maria Clara. Regulação do Exercício do Poder Paternal nos Casos de
} Divórcio. 4 ed. Coimbra: Almedina, 2008, p. 27. 
As mulheres, mesmo quando trabalham, ganham menos do que os homens, pois, nas empresas não se aplica o princípio do trabalho igual, salário igual. Por outro lado, as mulheres divorciadas são o grupo em que há mais mulheres desempregadas ${ }^{30}$ e, entre as mulheres autoras da ação de divórcio, existe uma elevada percentagem de mulheres com pouca instrução.

\subsection{0 controle judicial nos acordos de guarda}

O acordo dos pais relativo ao exercício do poder paternal, após o divórcio, quer se trate de litigioso ou consensual, está sujeito ao controle judicial. Na prática se confirma os acordos nos divórcios consensuais por falta de tempo, e de meios para se proceder uma investigação que permita um controle efetivo. O acordo é considerado como um bem em si e os juízes concentram seus esforços nos casos litigiosos.

Porém, não significa que um acordo num divórcio consensual esteja priorizando o bem estar da criança. Deve-se considerar que no momento do divórcio muitas vezes existem motivações pessoais e interesses econômicos que sobrepõem este interesse, além de alguns pais estarem em condições emocionais desfavoráveis para decidir.

No entanto, no caso de o MP recusar a homologação de um acordo terá que fundamentar esta decisão, pois deve-se respeitar o direito dos pais a educação dos filhos e sua liberdade de conviver com os mesmos.

Os casos típicos que exigem controle judicial são os de guarda alternada, deve-se proteger a criança que muitas vezes é utilizada como moeda de troca por um dos pais para obter vantagem financeira, quando o montante da obrigação de alimentos é inferior a necessidade real da criança,

\footnotetext{
${ }^{30}$ Cf. TORRES, Anália. O Divórcio em Portugal, ditos e interditos: uma análise sociológica. Oeiras: Celta Editora, 1996, p. 213-215.
} 
ou também quando um dos pais renuncia ao direito de visita ou à prestação de alimentos.

Também os acordos de guarda conjunta devem ser especialmente controlados a fim de se verificar se os pais não estão evitando uma decisão difícil e procuram a guarda conjunta para obterem uma vantagem financeira e não estão privilegiando a educação do filho. ${ }^{31}$

Quanto aos acordos de alternância de residência, salvo em casos excepcionais, não devem ser permitidos, sobretudo quando se trata de criança em idade pré-escolar. Caso se trate de filhos adolescentes, estes deverão ser ouvidos pelo tribunal para que se forme uma decisão favorável quanto à conveniência do acordo. ${ }^{32}$

\subsection{A mediação familiar}

O frequente descumprimento dos acordos de guarda após o divórcio levou a um projeto preventivo criado em maio de 1997, denominado "Mediação familiar em conflito parental" o seu objetivo era:

implantar um serviço de mediação familiar em matéria de regulação do exercício do poder paternal com caráter experimental, limitado a Comarca de Lisboa, fundando em equipes técnicas multidisciplinares, em articulação com os tribunais e acessível aos casais em situação de ruptura.

A mediação pretende ser um meio extrajudicial multidisciplinar de cooperação entre as partes para a resolução amigável de conflitos parentais que permite que os pais expressem suas emoções e dúvidas em relação a nova

\footnotetext{
${ }^{31}$ A este propósito vide o acórdão do Tribunal da RI de 18/01/2001, A nova redação do $\mathrm{n}^{\circ} 1$ do art.1906 do Código Civil, introduzida pela Lei 59, de 30 de 2006, veio permitir que os pais acordem que o poder paternal seja exercida em comum quanto às questões relativas aos filhos como se estivessem na constância do matrimônio. Tal, porém, não afetou o poder de o tribunal interferi ou não no acordo por via do disposto no art. $1905 \$ 1^{\circ}$ se estabelece que o acordo no divórcio está sujeito a homologação do tribunal que poderá recusá-lo se não corresponder ao interesse do menor.

${ }^{32}$ Sobre a relevância da idade do menor para o exercício conjunto do poder paternal com residência alternada vide infra, p.174-175.
} 
etapa da vida, orientados por profissionais que não mantém a relação hierarquizada tradicional num tribunal.

Porém existem críticas a este sistema, pois estudos revelam que o número de decisões de divisão da guarda física da criança em caso de relações parentais, altamente conflituosas é elevado (um terço das decisões de guarda conjunta), indicando que os mediadores familiares usam esta solução para resolver situações difíceis. ${ }^{33}$

Um assunto que diverge opiniões é a questão da guarda conjunta quando os pais estão em crise e numa relação conflituosa, segundo estudos sociais a manutenção da relação dos filhos com ambos os pais nessa situação é considerada danosa para estes onde se comprova que gera nos filhos perturbações no comportamento como agressividade e depressão. ${ }^{34}$

Por fim, a mediação familiar trata de um fenômeno chamado de desjudicialização do direito de família, permitindo a divisão de competências entre o julgador e profissionais das outras ciências sociais, procurando trazer celeridade nas soluções de acordo e também uma relação menos hierarquizada entre os pais e estes profissionais.

Não devemos, porém, desconsiderar que de qualquer forma se mantém o poder de investigação do juiz e do MP, pois este órgão é por excelência adequado a defesa dos direitos, liberdades e garantias dos cidadãos, sobretudo, dos mais fracos, as crianças.

\footnotetext{
33 MACCOBY, E.E.; MNOOKIN. R.H. Dividing the Child: Social and Legal Dilemamas of Custody. Cambridge. MA/London: Harvard University Press, 1992, p. 273.

${ }^{34}$ JOHNSTON, Janet R; LINE. Marsha; TSCHANN. Jeanne M. Ongoing Post divorce Conflict: Efects on Children of Joint Custod and Frequent Access. American Journey of Orthopsyquiatriy, 1989, v. 59, p. 576.
} 


\section{4. $O$ interesse do menor}

Após a reforma de 1977, se introduziu este conceito jurídico que é um conceito jurídico indeterminado muito utilizado que contém uma imensa complexidade. $\mathrm{O}$ legislador emite um comando ao tribunal a fim de que este decida de acordo com o interesse do menor, e a utilização deste conceito pelo juiz lhe confere poder de decidir no caso concreto.

Existem limites legais que dão um suporte lógico para esta decisão judicial como, por exemplo, o princípio da não discriminação dos pais em função do sexo, das concepções morais, raça ou religião e o respeito pela opção do menor. A fundamentação das sentenças também assume, um papel decisivo, pois permite aos seus destinatários identificar os fatores que levaram o juiz à decisão, permitindo-lhes recorrer ao tribunal superior em caso de abuso do poder discricionário.

Temos conceitos nucleares de interesse da criança que servem de critério para a escolha entre dois pais mais objetivos como quando um deles põe em risco a vida, a saúde física ou mental dos filhos e nos casos em que um dos progenitores não tem com o filho uma relação afetiva positiva, devido à ausência ou desinteresse deste pelo filho.

Esses casos são claros e objetivos, e não é difícil determinar a quem será confiada à guarda do outro progenitor, pois são critérios de exclusão onde se decide através de critérios legais, fornecidos pela Constituição e pelo Código Civil, quando consagram o direito da criança a proteção da sociedade e do Estado com objetivo de seu desenvolvimento integral (art.69, $\mathrm{n}^{\circ} 1 \mathrm{da}$ C.R.P.), o dever dos pais de promover o desenvolvimento físico, intelectual e moral dos filhos (art. $1885^{\circ} \mathrm{n}^{\circ} 1$ do C.C.) e de não pôr em perigo a segurança, saúde, a formação moral ou a educação do menor (art. $1918^{\circ}$ n. ${ }^{\circ} 1$ do C.C.).

Ocorre que nesses casos se decide por uma seleção negativa, mas o que se vê na maioria dos casos são pais igualmente ligados afetivamente a criança 
e capazes de cuidar dela, deixando o juiz com dificuldade de decidir critérios que são mais subjetivos. A este respeito diz CARBONNIER que os Tribunais de Família "tem de decidir de acordo com a sensibilidade". Por isto, conclui que esta é a originalidade da técnica legislativa dos conceitos indeterminados, quando aplicada ao direito de família: "a originalidade de não ser, como noutros lugares, pelo menos exclusivamente, um instrumento de adaptação racional, mas incluir pelo menos uma parte de variabilidade sentimental". A este propósito ainda diz o autor que o coração deve ter o seu lugar no direito com o mesmo título da razão. Trata-se de um novo campo a investigar a lógica do coração. ${ }^{35}$

Mas retornando aos critérios objetivos a guarda do menor deve ser confiada ao progenitor, em caso de litígio, que promova o seu desenvolvimento físico, intelectual e moral, e que tenha disponibilidade para satisfazer as necessidades do menor e que tem com este uma relação afetiva mais profunda. A preferência da criança, quando esta queira e possa exprimi$1 \mathrm{l}^{36}$ e coincidirá com os critérios anteriores.

Para melhor formar estes elementos, o tribunal pode ordenar um inquérito sobre a situação social, moral e econômica dos pais e da criança e ordenar a realização de exames psicológicos aos pais e aos filhos sobre a personalidade destes e sobre a dinâmica de suas relações mútuas (art. 178 $\mathrm{n}^{\mathrm{o}} 3$ OTM). O tribunal pode também ouvir os seus avós, o menor e outros parentes (art $175^{\circ}$, n. $^{\circ} 1$ OTM) e as testemunhas oferecidas pelos pais. (art. $178 \mathrm{n}^{\circ} 2$ OTM).

\footnotetext{
35 CARBONNIER, Jean. Les Notion a Contenu Variable em Droit. Bruxeles: Chain Perelman et Raymond Vander Elst, 1984, p.110-111.

${ }^{36}$ A criança tem também o direito de se afastar o processo e de não ser pressionada a optar por um dos pais. Sobre este direito do menor vide GOMES, Júlio. A Mediação e o Divórcio. A Experiência Norte-Americana. Scientia Jurídica. Tomo XXXVIII, 1989.
} 


\subsection{A preferência maternal para a criança de tenra idade}

A criança de tenra idade é regra que deva ficar com a mãe, sendo acompanhada com outras regras como a não separação dos irmãos e a preferência ao progenitor que tem o mesmo sexo da criança, quando não é de tenra idade. ${ }^{37}$

A preferência maternal não constitui uma violação do princípio da igualdade quando acompanhada de fatores, que avaliados pelo julgador, à luz do interesse da criança, apontam para que a guarda seja confiada à mãe. Trata-se apenas de um argumento retórico da fundamentação da sentença e não uma discriminação em razão do sexo. ${ }^{38}$

Essa preferência maternal é resultado da luta das feministas no período da revolução industrial, em cuja época a criança era considerada propriedade paterna. ${ }^{39}$ Inicialmente, esta regra era aplicada em crianças até três anos de idade, e não em crianças mais velhas. ${ }^{40}$

A aplicação generalizada da preferência materna só ocorreu com a Reforma de 1977, sendo a questão da guarda dos filhos vista à luz da

\footnotetext{
${ }^{37}$ Acórdão da Relação de Évora, de 19/05/1979, B.M.J, 290, P.488.

${ }^{38}$ SOTTOMAYOR, Maria Clara. Exercício do poder Paternal relativamente à pessoa do filho após o divórcio ou a separação judicial de pessoas e bens. Universidade Católica Portuguesa. Portugal: Editora Porto, 1995, p. 160-161.

${ }^{39}$ MASON, Mary Ann. Fron Father's Property to Chrildren Rights. The History of Chrildren Custody in the United States. New York: Columbia University Press, 1994.

${ }^{40}$ No direito antigo, a mãe tinha a guarda dos filhos até aos três anos de idade, e o pai após aquela idade. (Ordenações, L1 tit. 88, 10 e L4, tit.99). No domínio do Código Civil de 1867, seguia-se a mesma regra da guarda maternal até aos três anos de idade. Veja-se que no art.1136 se dispunha que os filhos menores de três anos são confiados ao cuidado da mãe in DIAS FERREIRA, Código Civil Português Anotados, vol, III, Imprensa Nacional, 1872, p.46. Na Lei do Casamento de 1910, a regra da preferência maternal foi alargada. Em caso de anulação do casamento, as crianças do sexo feminino de todas as idades e do sexo masculino até os seis anos de idade eram confiadas à mãe, se ambos os cônjuges estivessem de boa-fé (art. $\left.34^{\circ}\right)$. Se mãe estivesse de má-fé, mesmo assim assumiria a guarda dos filhos até os três anos de idade sem distinção de sexo $\left(\operatorname{art} .35^{\circ}\right)$. Estas regras eram aplicadas analogicamente aos casos de divórcio. Cf. CUNHA GONÇALVES. Tratado de Direito Civil. V. VII, Coimbra, 1932, p.104.
} 
maternidade e do caráter insubstituível da mãe na educação dos filhos, sobretudo quando é da tenra idade. ${ }^{41}$

Enfim, a preferência matriarcal para crianças de tenra idade representa um triunfo do interesse do menor, em relação ao seu laço emocional com sua mãe que cuida dele em sua maioria no dia-a-dia sobrepondo os critérios patriarcais, que seguiam o direito romano onde o filho era mera propriedade do pai.

Em Portugal o critério de preferência maternal tem sido dominante na jurisprudência até à última década, altura em que na jurisprudência publicada se registraram mudanças relativamente aos critérios de decisão tradicionais. ${ }^{42}$

Os tribunais citam simultaneamente o Princípio VI da Declaração Universal dos Direitos da Criança de 1959: "a criança de tenra idade não deve, salvo em circunstâncias excepcionais, ser separada da mãe”. Esta regra funciona como uma presunção judicial somente excluída no caso da mãe ser comprovadamente incapaz de cuidar adequadamente de seu filho por comportamentos amorais ou estados mentais desajustados. ${ }^{43}$

É importante ressaltar nessa discussão que atualmente a jurisprudência tem criticado a preferência maternal, especialmente por parte da classe média urbana, através de associações de pais divorciados que defendem os direitos

\footnotetext{
${ }^{41}$ Acórdão da Relação de Évora, de 12 de Julho de 1979, in Infância e Juventude, 1980 no 3, p.51: "A orientação jurisprudencial dominante, segundo a qual pela natureza das coisas, pelas realidades da vida quotidiana, por razões que se prendem a com a própria natureza humana, uma criança de tenra idade deve, em regra, ser confiada à guarda e cuidados da mãe, salvo se existirem razões poderosas em contrário, não viola qualquer norma constitucional.

${ }^{42} \mathrm{Na}$ Jurisprudência não publicada continua a seguir-se o critério de preferência maternal. Vide os acórdãos do Tribunal da Relação do Porto de 28/10/1997 onde se afirma o seguinte: “A mãe é o progenitor naturalmente mais dotado para proporcionar ao filho o carinho e a compreensão necessários aos desenvolvimentos harmônicos da personalidade deste". "Um filho de tenra idade não deve ser separado da mãe, a não ser por razões excepcionais e interesse do próprio menor, aconselhem solução diversa". Entre outros, na sua maioria no mesmo sentido.

${ }^{43}$ Vide o acórdão do Tribunal de Relação do Porto de 30/04/92, in base de dados do MJ: "Em princípio, segundo a jurisprudência, deve ser entregue a mãe a criança de tenra idade, a monos que a circunstâncias excepcionais o desaconselhem; Assim, apesar de muito amor e carinho que a mãe, como o pai demonstram pelo filho menor, com três anos de idade, é de se confiar este aos cuidados daquele se se prova que a mãe padece de oligofrenia, no grau débil mental, relevando grande dificuldade de autodeterminação.
} 
do homem nas decisões de guarda dos filhos. Hoje se discute os novos papéis que o homem e a mulher desempenham na família e o gradual desaparecimento da mãe tradicional dona de casa e totalmente dedicada aos filhos.

Mas por outro lado, o fato de a mãe trabalhar fora integralmente não é motivo para perder a guarda, pois seria uma punição do tribunal à mulher que tem uma dupla jornada. E se estaria associando a figura da mãe adequada a dona de casa do século passado. ${ }^{44}$

Enfim dentro desse contexto onde a transformação dos papeis do homem e da mulher não pode ser utilizada como critério para decidir os conflitos na regulação da guarda após o divórcio temos estudos que demonstram que nas camadas sociais mais desfavorecidas praticam-se modelos rígidos de divisão de tarefas e, mesmo casais com instrução universitária, embora defendam a igualdade de valores, só uma minoria os pratica.

\footnotetext{
44 Sobre a discriminação das mulheres aos processos de regulação do poder paternal vide POLIKOFF, Nancy. Why Mothers are loosing. A Brief Analysis of Criteria Used in Child Costody Determinations. Womens Law Reporter, vol.7, $\mathrm{n}^{\mathrm{o}} 3$ 3, 1982, p. 236 e ss. A autora refere três grupos de fatores que contribuem para prejudicar a mãe: a) os recursos econômicos mais elevados do pai; b) o trabalho da mulher; c) o segundo casamento do pai. Estudos feitos na Suíça revelam que os pais que num processo litigioso assumem a guarda dos filhos, são homens com uma melhor integração social e estabilidade profissional e com rendimentos mais altos, quando comparados com as mulheres, que geralmente tem um nível econômico mais baixo
} 


\section{PARTE IV- O EXERCÍCIO DO PODER PATERNAL E MODELOS DE GUARDA}

\subsection{O modelo de guarda única}

O modelo de guarda única ou exercício unilateral do poder paternal pressupõe um conflito de soma zero em que aquilo que um dos pais ganha é igual ao que o outro perde. É um sistema de tudo ou nada que os americanos designam por "Winner take all" e os alemães por "Alles ode nichts".

Os poderes-deveres que integram o conteúdo do poder paternal (art. $1878^{\circ}$ ) passam a ser exercidos pelo progenitor à quem a criança é confiada (art. $1906^{\circ}$ ). O guardião detém o direito de fixar a residência da criança e coabitar com esta e assume o essencial das responsabilidades educativas em relação ao menor, quanto a sua formação escolar, cívica, religiosa e ainda a responsabilidade pela proteção física e moral daquele, assegurando ao menor todos os cuidados materiais e afetivos necessários ao desenvolvimento de sua personalidade.

Quanto ao progenitor sem a guarda, este apenas detém a titularidade do poder paternal, mas não está legalmente autorizado a exercê-lo nem a participar nas decisões de particular importância relativas à educação do menor. O seu papel limita-se ao de um observador passivo, desprovido de poderes decisórios em relação à pessoa do filho. Os seus direitos resumem-se a um direito de manter relações pessoais com o filho (o direito de visita) e controlar o modo como o filho é educado pelo progenitor a quem foi confiada a guarda (o direito de vigilância). ${ }^{45}$

45 SOTTOMAYOR, Maria Clara. Regulação do Exercício do Poder Paternal nos Casos de Divórcio. 4. ed. Coimbra: Almedina, 2008, p. 138. 


\subsubsection{Críticas a guarda única}

A mãe, a quem geralmente a guarda é atribuída, sente-se sobrecarregada econômica, física e psiquicamente. A queda em seu padrão de vida, lhe obriga a trabalhar mais tempo, ficando menos disponível para cuidar dos filhos.

O pai, a quem a guarda foi negada, sente-se excluído da educação e da vida de seus filhos, encontra-se com sentimentos de perda e de luto, o conduz normalmente a uma diminuição das visitas ou até sua completa supressão. ${ }^{46}$

É negado à criança um contato diário com o progenitor sem a guarda, com seu estilo de vida e a sua visão do mundo. Prejudicando uma relação mais profunda entre pai e filho, pois na visita se perde a naturalidade que caracteriza uma relação no seu dia-a-dia. ${ }^{47}$

Todo este quadro aponta no sentido de que a guarda única cria desequilíbrio e desarmonia na estrutura familiar pós-divórcio.

\subsection{A guarda conjunta}

\subsubsection{Origens e razões de seu surgimento}

Em 1995 a lei 84 de 31 de agosto alterou o Código Civil e introduziu a possibilidade de os pais optarem pelo exercício conjunto do poder paternal (art.1906, $\mathrm{n}^{\circ} 2$ ) ou de acordarem que determinados assuntos sejam resolvidos por acordo de ambos (art.1906 n³). A principal razão invocada para introduzir no Código Civil o exercício conjunto do poder paternal residia no interesse da criança, entendido como as necessidades afetivas e emocionais desta a conviver com ambos os pais após a separação destes, considerando

\footnotetext{
${ }^{46}$ GRIMALDI, Maria Rosa. Affidamento Congiunto e Alternato dela Prole tra Psicologia e Diritto. DFP, vol. XVIII, 1989, Pit., p. 321.

${ }^{47} \mathrm{Cf}$. A este propósito a autora sugere ver Ibid. e nota 52, onde baseando-se em autores americanos DREYFUS. Cousenling the Divorced Father. Journal of Marriage and Family Therapy, n5, 1979, p. 79, onde diz exatamente que os encontros vão se rareando, nas visitas.
} 
os autores do projeto que este contato torna o divórcio menos traumático para todos e promove seu amplo desenvolvimento psicológico.

Mas o que gerou está nova forma de guarda foi a insatisfação relativamente às consequências da guarda única, onde se visava por um lado garantir o direito da criança de relacionar-se com ambos os pais e por outro que promovam a igualdade de direitos e de responsabilidades.

Como soluções alternativas ao sistema tradicional, surgem assim, o exercício conjunto do poder paternal, ou, onde a possibilidade de cooperação entre os pais, após o divórcio, nasce da transformação profunda das relações familiares tradicionais, através de uma cultura centrada nos direitos da criança e de uma sociedade de tendências igualitárias.

A desdramatização do divórcio permite a manutenção de uma cooperação entre os pais relativamente aos filhos. Neste sentido, invoca-se o caráter indestrutível dos laços entre os pais e os filhos e a sobrevivência da comunidade parental para além da dissolução da comunidade conjugal. ${ }^{48}$ As ciências sociais falam a este propósito de uma mudança de concepção de família que passa a ser entendida como um sistema que não se dissolve após o divórcio, apenas se reestrutura. ${ }^{49}$ Está ideia de família visa exprimir que todos os membros da família estão ligados por uma experiência comum de amor e de contato social. ${ }^{50}$

Esta mudança de comportamento no seio das famílias desunidas é o reflexo de uma evolução sociológica e de mentalidades, traduzidas na fungibilidade de papéis do homem e da mulher no mercado de trabalho e na

\footnotetext{
${ }^{48}$ Cf. GUY RAYMOND. De la realité du couple conjugal a la fiction de l' unité du couple parentale. Comentaire de l loi, $\mathrm{n}^{\circ}$ 87-570, juillet 1987 J.C.P, I, 3299.

${ }^{49}$ Cf. FTHENAKIS; WASSILIOS E. Gemeinsame elterliche Sorge., p. 5.4.3.

${ }^{50}$ Cf. RAINER BALLOF. Gemeinsame elterliche Sorge als Regelfall? FamRZ, v.90, 2.2.
} 
família, no fenômeno novos pais ${ }^{51}$, na paternidade responsável e na igualdade dos sexos que caracteriza a evolução contemporânea da família. A igualdade na atribuição de guarda, após o divórcio, traduz-se na necessidade de assegurar a ambos os pais um papel efetivo na educação da criança. Para promover este objetivo criou-se a associação de homens divorciados, contestando a guarda maternal e o papel reduzido na vida dos seus filhos. ${ }^{52}$

Em Portugal, o início do movimento feminista no princípio do século XX também esteve associado para além da luta dos direitos das mulheres, à proteção dos direitos das crianças, sendo nesta época que surgem as primeiras obras de apoia às crianças e às mães, criadas pela Liga Republicana de Mulheres Portuguesas. ${ }^{53}$

Enfim, o exercício conjunto do poder paternal reflete mais uma ideologia do que uma realidade social, pois nas práticas familiares se vê um desencontro da Lei onde na maioria dos casos de divórcio são as mães que continuam cuidando dos filhos, e mantém uma relação afetiva mais próxima.

As normas que consagram o princípio da igualdade de direitos e deveres dos cônjuges, a direção conjunta da vida familiar (art.1671º ) e exercício conjunto do poder paternal, na constância do matrimonio (art.1902º deve contribuir ao longo prazo que esse papel conjunto deve ser mantido igualmente após o divórcio, pois este, não deve tirar a finalidade maior de ambos protegerem o interesse da criança.

\footnotetext{
${ }^{51}$ Expressão usada por HUGHES FULCHIRON. Autorité Patentale et Parents Désunis., p.20 para se referir a maior participação do pai na educação do filho mesmo tratando-se de crianças de tenra idade.

${ }^{52}$ MASON, Mary Ann. Fron Father's Property to Chrildren Rights., p 12-17 e FINEMAN, Martha A., The Neutered Mother...

${ }^{53}$ ESTEVES, J.G.. A Liga Republicana das Mulheres Portuguesas. Uma organização política e feminista (1909-1919). 1991, p. 78-81. P. 67-100.
} 


\subsubsection{Modelos na Lei da Guarda Conjunta}

A Lei portuguesa consagra essa possibilidade de guarda conjunta semelhante aos direitos e deveres cujos pais tinham quando casados, para isto basta que haja à existência de um acordo dos pais neste sentido.

O exercício conjunto do poder paternal pode ser exercido de várias formas $^{54}:$ 1) o exercício conjunto mediante acordo dos pais homologado pelo juiz; 2) exercício conjunto como uma opção judicial, independente do desejo dos pais; 3) exercício do conjunto do poder paternal como princípio regra após o divórcio, constituindo o exercício unilateral uma solução excepcional a ser decretada a pedido de um ou ambos os pais, se existirem motivos especiais para que a isso conduzam ${ }^{55}$.

A Lei portuguesa optou bem em restringir o exercício conjunto do poder paternal apenas nos casos em que tal princípio resulte de um acordo entre ambos os pais, pois este exercício requer cooperação e comunicação frequente entre os pais e não funcionaria com êxito se estes tivessem um péssimo relacionamento e mesmo não desejassem compartilhar a guarda.

A imposição da guarda conjunta contra a vontade de um ou de os pais pode provocar litígios entre os pais e recursos nos tribunais para resolver estes conflitos em torno da educação da criança compartilhada, esta situação

\footnotetext{
${ }^{54}$ Encontramos este tipo de legislação de guarda conjunta nos EUA, nos estatutos dos 33 estados que optaram pela guarda conjunta. Existem quatro tipos de legislação do ponto de vista de condições mediante as quais o tribunal tem o poder de decretar a guarda conjunta: a) a guarda conjunta como opção judicial, independente do desejo das partes; b) guarda conjunta como uma opção judicial mas só quando as partes concordarem; c) guarda conjunta como opção requerida por uma das partes; d) preferência ou presunção da guarda conjunta.

${ }^{55}$ Este peso atribuído ao exercício conjunto do poder paternal é defendido nos EUA por parte da doutrina, com base na proteção constitucional da relação pais-filhos pelo Fourteenth amendement da Const.dos EUA, onde após o divórcio um dos pais poderá ficar privado da guarda do filho apenas se apresentar a criança um perigo sério ou no caso de ser incapaz de a educar. Cf. PATRICIA GROVE, Joint Custody. A Concept That has come of age but needs refiement. American Journal of Family Law, volume 1, nº 1, Spring 1987, p.50 nota 7.
} 
prejudicaria o interesse da mesma fazendo com que seja muitas vezes manipulada pelos pais para um agredir o outro.

Por outro lado, a possibilidade de o juiz decidir nesse sentido para evitar uma decisão subjetiva quando temos ambos os progenitores aptos para cuidar da criança, porém, a convivência diária não é positiva para a criança que acaba sendo prejudicada por esta decisão.

No entanto o fato de que para ser aprovada a guarda conjunta exige um acordo prévio de ambos os pais, dá a um deles um poder de veto, lhe dando de certa forma um meio de manipulação e dependendo do mau caráter de chantagear o outro genitor que deseja a guarda conjunta.

O modelo da guarda conjunta como uma preferência legal ou presunção ${ }^{56}$, seguindo o princípio de que a maioria dos pais tem após o divórcio, tem plena capacidade de cuidar dos filhos numa forma de cooperação só é afastada quando os fatos e circunstâncias do caso concreto demonstram que um dos genitores não está apto para fazê-lo, demonstrando que traria inconvenientes para a criança.

Enfim, em Portugal ainda é prematuro a consagração de um princípio regra de exercício conjunto de poder paternal após o divórcio, todavia, o aumento do número de divórcios não conflituais, a aceitação da sociedade progressiva do divórcio, a fungibilidade de papeis entre homem e mulher, e o aparecimento de casais que mantém após o divórcio uma relação amigável tornam possível, que havendo um acordo entre os pais para o exercício

\footnotetext{
56 A preferência pela guarda conjunta traduz-se normalmente no princípio consagrado legislativamente segundo o qual o interesse da criança é prosseguido por um contato contínuo de ambos os pais. Ver, a título de exemplo, os estatutos do Estados de Iowa. California Kansas e New Hampshire. Cfr. PATRICIA L. GROVE. Joint Custody. A Concept That has come of age but needs refinement., p.52. nota 31. California e Kansas têm uma presunção em caso de acordo e uma preferência em caso de falta de acordo, Ibid, p. 52 nota 31.
} 
conjunto do poder parental este seja estipulado cada vez mais frequentemente.

\subsection{O exercício do poder paternal na Legislação Civil}

O Código Civil de 1867 dissociava a guarda do exercício do poder paternal, pois, quando a guarda dos menores era confiada à mãe, o pai continuava a exercer, seguindo o direito romano, o poder dever de representar os filhos menores de administrar seus bens e dirigir sua educação.

No mesmo sentido o Código Civil de 1966, atribuía ao pai o poder de representar o filho, administrar seus bens e decidir sobre sua vida em geral inclusive autorizá-lo a exercer uma profissão ou consentir na sua emancipação (art.1881 $)$. A mãe tinha apenas o direito de ser ouvida e de participar em tudo que dissesse respeito ao interesse do filho e exercia o poder paternal somente no caso de ausência ou impossibilidade do pai $\left(\operatorname{art} .1882^{\circ}\right)$.

O CC não previa solução para o exercício do poder paternal após o divórcio ou separação dos pais. Na prática a mãe que detinha a guarda dos filhos estava colocada na dependência da autorização do pai do menor para tomar qualquer decisão relativamente à pessoa e aos bens de seu filho, além de ter que se sujeitar a interferências daquele na educação do menor.

Porém, com o artigo 1906, nº1 do Código Civil na redação da Reforma de 1977 introduziu-se o princípio do exercício do poder paternal pelo progenitor a quem o menor foi confiado, com o objetivo de proteger o menor dando-lhe uma estabilidade em sua vida, e evitando os conflitos entre os pais nas decisões de sua vida. É fato que o progenitor residente que educa o menor no dia-a-dia que tem em virtude dessa proximidade melhor condição de tomar decisões de particular importância relativamente a este.

Em 1995, a lei 84/95 de 31 de Agosto alterou o Código Civil introduziu a possibilidade dos pais optarem pelo exercício conjunto do poder paternal 
(art.1906, $\mathrm{n}^{\circ} 2$ ) ou acordarem que determinados assuntos sejam resolvidos por acordo entre ambos (art.1906, n³), vigorando que na falta de acordo dos pais prevalecerá o princípio do exercício unilateral do poder paternal pelo progenitor a quem for atribuída a guarda do filho (art.1906, nº1). Essas alterações ao Código Civil resultaram de uma proposta preparada pela Associação Portuguesa de Mulheres Juristas e pela Instituição Pai-MãeCriança, ${ }^{57}$ a qual pretendeu traduzir convergindo o interesse da criança com a igualdade de direitos e deveres dos pais.

O que se buscava com essa nova lei era o melhor interesse da criança, a diminuição da sobrecarga da mãe em educar o filho e a responsabilização do pai. Deve-se ressaltar que os pais através de associações que reivindicavam maior presença na vida dos filhos e igualdade de direitos após a separação.

De acordo com a ratio legis do art.1906, $\mathrm{n}^{\circ} 1$, o exercício conjunto do poder paternal é uma solução para casos excepcionais, em que os pais revelam capacidade em cooperar entre si e de separar os seus problemas enquanto cônjuges do seu papel como pais, se respeitam um ao outro como pessoas e confiam um no outro como pais, têm ambos capacidade educativa e uma boa relação afetiva com o filho, e a solução escolhida não prejudica o interesse do menor.

O atual artigo $1906^{\circ}$ da lei $n^{\circ} 59 / 99$ refere ao exercício conjunto do poder paternal dependente de acordo entre os pais, e que a princípio, em casos de falta de acordo a guarda continua a ser do progenitor a quem o filho foi confiado, e esta será sociologicamente a solução majoritária.

${ }^{57}$ RIBEIRO, Maria Saldanha Pinto. O Divórcio e a Guarda Conjunta, Lisboa Centro Pai-MãeCriança. Associação Portuguesa de Mulheres Juristas, 1994 e DAR, 5 de janeiro de 1995, II Série. A-No11. Projeto de Lei no 475/VI, p.124-125 
Quanto ao dever de fundamentação do juiz no caso, de ausência de acordo dos pais, a lei não especifica quais os critérios que deve o juiz recorrer para afastar o exercício conjunto do poder paternal. Deve-se entender-se que basta ao juiz alegar a impossibilidade de se obter um acordo. ${ }^{58}$

A recusa de um dos pais é considerada pela lei uma presunção iuris et de iure de que falta, aos pais, a capacidade de cooperação para pôr em prática o exercício conjunto do poder paternal. Este dever de fundamentação do juiz, é necessário para afastar a possibilidade do exercício conjunto do poder paternal, parece impositivo, sem, contudo, lhe permitir impô-la.

Já a alteração do artigo $1906^{\circ} n^{\circ} 1$ do Código Civil não reflete uma preferência do legislador pela guarda conjunta, sendo esta uma solução deixada a opção em consenso dos pais a fim de evitar que se prejudique o menor, e mantém a autonomia da família evitando uma imposição judicial.

Os casos de acordo de guarda conjunta resultam na prática de uma força de vontade profunda de ambos os pais, que conseguirem manter uma relação harmônica, mesmo separados e que põem os interesses dos filhos acima dos seus procurando educa-los conjuntamente, e esse tipo de genitor o faz independente da norma legal.

Na prática a jurisprudência entende que a guarda conjunta só pode ser decretada quando existe acordo entre os pais, espírito de colaboração e capacidade de diálogo, constituindo a solução regra a guarda unilateral.

\footnotetext{
${ }^{58}$ Veja-se a esse propósito o acórdão do Tribunal da Relação do Porto de 26/05/2000, in Base Jurídico documental do MJ: "Na falta de acordo dos pais(separados), o poder paternal será exercido pelo progenitor a quem o filho foi confiado, podendo o outro progenitor vigiar as condições de vida e a educação do filho. O que não pode é confiar-se o menor a um progenitor e manter, na falta de acordo, o exercício em comum do poder paternal. A lei terá querido evitar as constantes intromissões do progenitor a quem não foi confiado o menor sem prejuízo do poder de vigilância”.
} 


\subsection{Pressupostos do exercício conjunto do poder paternal}

Mas um dos pressupostos que deve se considerar é a idade da criança, onde a alternância de residência é uma solução para crianças mais velhas, dotadas de certo grau de maturidade e de autonomia, mas não para criança de tenra idade, as quais não devem ser separadas da mãe, pois a criança nessa primeira fase de vida tem como aspecto essencial para sua sobrevivência é o da nutrição.

Para que essa guarda seja exercida corretamente devem os pais revelar uma capacidade de cooperar e de educar em conjunto a criança, separando seus conflitos interpessoais dos seus papéis enquanto pais e educadores e que acima de tudo mantenham uma boa relação afetiva com o filho. Deve-se analisar se tal medida afeta o interesse da criança e ter-se em conta a necessidade desta e seu grau de desenvolvimento e no caso de filhos mais crescidos a sua opinião também deve ser considerada.

Por vezes, a jurisprudência coloca ainda mais exigências aos pais, como por exemplo, uma identidade de valores, sejam morais, religiosos, programas educativos quanto à saúde, disciplina, tudo isso para que o filho encontre uma coerência de modelos em ambas as residências que vai frequentar. Alguns casais após a separação procuram residir próximos, a fim de que de todas as formas procure-se bons candidatos para a guarda conjunta. Estes pais devem ser capazes de dar prioridade as necessidades de seu filho, e aceitam a importância de uma relação próxima da criança com o outro progenitor, que têm respeito e confiança um no outro como pais e que mostram um nível razoável de cooperação e vontade de colaborar. ${ }^{59}$

\footnotetext{
${ }^{59}$ Um estudo realizado na Alemanha demonstra que cerca de $25 \%$ dos pais apresentam estas características, embora apenas uma percentagem muito inferior (cerca de $6 \%$ ) adote efetivamente a guarda conjunta, após o divórcio. Cf. OLLMANN. op.cit., p.870.
} 
Um importante estudo realizado na Alemanha desmentiu a convicção de que a guarda conjunta pressupunha um alto nível intelectual dos pais. A prática demonstra que a guarda conjunta se distribui igualmente por todos os estratos e profissões. ${ }^{60}$ Constatou-se também que a guarda conjunta partir de decisão, em sua maioria, dos pais e não do tribunal. Os casos em que houve uma alteração da decisão inicial forma casos em que a guarda conjunta foi decretada sem a vontade real de um dos pais, o que confirma a ideia de que a guarda conjunta exige um acordo sincero e conjunto por parte dos pais.

Veio-se a verificar que os pressupostos exigidos pelo Tribunal Constitucional Alemão para ser possível o exercício do poder paternal, são essenciais para que este possa ser decretado: 1) ambos os pais devem ter vontade de exercer em conjunto o poder paternal; 2) ambos os pais são plenamente capazes de educar a criança; 3) não existe nenhum motivo que revele que o interesse da criança exige que seja decretada a guarda única. ${ }^{61}$

O acordo pode ser pormenorizado, dependendo do grau de exigência dos pais, ou vago se limitando a organizar a convivência com ambos os pais, deixando à vontade todos os pormenores, constituindo a guarda conjunta como um hábito que se vai construindo no dia-a-dia.

Porém, para evitar futuros conflitos e para orientar os pais e procurando diminuir desgastes é preferível um acordo pormenorizado, devendo conter

\footnotetext{
${ }^{60}$ OELKERS KAS TEM/OELKERS. Das gemeinsame Sorgerecht nach Scheidung in der Praxis des Amtsgerichts Hamburg - Familiengericht, ob, cit. p. 1081.

${ }^{61}$ O direito alemão foi alterado em 1977, passando o $\$ 1671$ a consagrar o princípio-regra do exercício conjunto do poder paternal, após o divórcio, sendo apenas decretado a guarda unilateral com o consentimento dos pais e dessde que esta seja a solução mais conforme ao interesse dos filhos. Contudo a Jurisprudência evolui da consideração da qual a guarda conjunta como princípio-regra para uma solução mais restritiva segundo a qual a guarda conjunta não tem primazia sobre a guarda única e nem existe qualquer presunção legal de guarda conjunta. BORN, winfried, Gemeinsomes Sorgerecht: Ende der mordernen Zeiten, Besprechung Von BGH, Urteil v 29.9.1999 - XII ZB 3/99 Fan RZ, 1999, 1646, p. 396-399.
} 
um plano em relação a educação do filho, com a indicação da residência e do ritmo de alternância desta com direitos e deveres de ambos os pais.

Deve-se ressaltar que o controle desses acordos depende de uma avaliação judicial que abrange diversos pressupostos subjetivos (capacidade de cada um dos pais de conter a sua hostilidade, em relação ao outro, diante da criança; os motivos dos acordos dos pais, ou seja, saber se uma decisão apressada que muitas vezes visa um divórcio célere; a estabilidade e a maturidade emocional dos pais; a manutenção de uma boa relação entre eles; capacidade de comunicação entre os pais e a vontade da criança) e pressupostos objetivos (proximidade das residências ou possibilidade de comunicações fáceis e frequentes, condições de habitação de cada um dos pais etc.).

O pedido de guarda sempre deve envolver preocupação e afeto pelos filhos e um empenho real em sua educação e em acordo com as necessidades da criança ou adolescente, pois esta tem seus pais como fonte de segurança e amor.

\subsection{Vantagens e inconvenientes do exercício conjunto do poder paternal}

A guarda conjunta é encarada por uns com otimismo, e como um avanço para a solução de problemas gerados nas crianças após o divórcio e por outros com ceticismo considerando ser uma fonte nova de conflitos entre os pais trazendo instabilidade para a criança.

Estudos realizados nos $\mathrm{EUA}^{62}$ demonstram que a guarda conjunta legal não é nem a solução para os efeitos do divórcio, nem uma fonte de conflitos

\footnotetext{
${ }^{62}$ CATHERINE L. ALBISTON; ELEANOR E.MACCOBY. Does joint legal custody really matter? Este estudo incide sobre famílias, em que o divórcio foi decretado e a guarda dos filhos determinada em Setembro de 1989, 328 famílias estavam submetidas ao regime de guarda conjunta legal e 121 a uma decisão de guarda maternal. A informação foi obtida através de duas fontes: a gravação judicial e entrevistas telefônicas com os pais, que demoravam uma hora. As famílias em guarda conjunta foram comparadas com as famílias de guarda única maternal, com base nos seguintes critérios 1)
} 
nas famílias afetadas por tal situação. Os autores concluem que os dados recolhidos sugerem que a guarda conjunta legal não tem qualquer efeito significativo em nenhum desses aspectos (visitas durante à noite, contato com o pai e envolvimento desse no processo de decisão; relação entre os pais e apoio financeiro), uma vez tomada em conta as diferenças iniciais entre o grupo de família em guarda única e o grupo de guarda conjunta legal. Porém consideram positivo que ambos os pais sejam igualmente responsáveis pelo cuidado e educação dos filhos.

A vantagem que se vê neste tipo de guarda em que a criança mantém contato com ambos os pais, é que se atenua o sentimento de luto e de abandono normalmente associado ao divórcio. A criança manteria, assim, dois progenitores psicológicos que contribuiriam para a formação de sua personalidade de uma forma mais diversificada e completa. A criança teria em relação ao tradicional regime de visita mais tempo de convivência com o pai e qualidade deste, pois envolveria a coabitação com proximidade e mais naturalidade.

Um grupo de feministas alertam para o risco de se conceder a guarda conjunta para mulheres que contenham um histórico de violência doméstica, pois a guarda conjunta as forçaria de manter contato com o ex-marido deixando-a sujeita a abusos. No entanto, para outras autoras, também feministas, a guarda conjunta diminui a sobrecarga que exigia da mulher toda responsabilidade de educar os filhos, mas não deve ser dada a casais que contém histórico de violência doméstica.

Diz-se ainda que a igualização dos direitos e responsabilidades dos pais diminui os conflitos e encoraja a cooperação entre eles, ${ }^{63}$ pois deixa de haver

envolvimento (visitas durante à noite, contato com o pai e participação dos pais nas decisões; 2) relação parental; 3) apoio financeiro.

${ }^{63}$ Os estudos citados por FRANZ DICKMEIS. Die gemeinsame Sorge - einengagiertes Pladoyer, 1989 p.57. 
um perdedor e um vencedor, o que reduz uma competição que pode resultar em agressões mútuas na presença do filho. ${ }^{64}$ Por outro lado, mesmo que inicialmente resista uma conflitualidade entre os pais, com a passagem do tempo tende a ser ultrapassados as dificuldades diárias e há uma adaptação à nova realidade.

Por outro lado, os opositores da guarda conjunta afirmam que esta, quando envolve uma alternância de residência, provoca à criança grande instabilidade, sensações de ansiedade e de insegurança. Além de ter duas rotinas diferentes, casas diferentes que pode gerar uma fantasia de reconciliação na criança. ${ }^{65}$

Conforme a idade das crianças, as consequências da guarda conjunta são as seguintes: As crianças de 3 a 5 anos mostram mais perturbações de comportamento do que as de 1 a 2 anos: pesadelos crônicos e nervosismo ocasionados pelas mudanças a que estão sujeitas. ${ }^{66}$ A razão que explica essa situação é que as crianças desta idade enfrentam complexos desafios de desenvolvimento.

As crianças que já estão na escola primária, são as que apresentam mais capacidade para se adaptarem as mudanças que a guarda conjunta oferece. Porém, prefeririam ter uma casa só com menos alterações em sua rotina. Contudo, o contato com ambos os pais e o recurso de duas casas podem influenciar positivamente na sua capacidade de adaptação a em estágios posteriores de seu desenvolvimento.

\footnotetext{
${ }^{64}$ Contudo, o fato do exercício do poder paternal ser conjunto não atenua necessariamente o conflito entre os pais quanto ao destino dos filhos, pois permite que este se desloque da questão da atribuição da guarda para a fixação da residência da criança. Afirma-se mesmo que normalmente o conflito dos pais se situa em torno da residência da criança e não em torno de questões mais complexas.

65 RAINER BALLOF. . Gemeinsame elterliche Sorge als Regelfall?, p. 447-448; JACK WESTMAN. Joint Custody from the Child's point of view, in Joit custody. A handbook for judges, lawyers and counselo rs. The Association of Family Courts. May 1979, p.B39 e ss.

${ }^{66}$ ROSEMARY MCKINNON; JUDITH WALLERSTEIN. Joint custody and the prescooler childa. Behavior Scienses and The Law, vol 4, n² 1986, p.169. As investigações incidiram sobre 25 famílias com crianças de idade compreendida entre os 14 meses e os 5 anos, durante os anos de 1981 a 1985. Das crianças de 1 a 2 adptaram-se bem 3 em 7. Tal deve-se a cooperação entre os pais que isolam seus conflitos pessoais da relação com a criança.
} 
A guarda conjunta quando acordada pelos pais, favorece ao homem a se sentir mais comprometido com a educação do filho, estimulando que se aproxime dele e incentivando que o apoie financeiramente, mas a execução da guarda requer que os dois pais sejam capazes de manter um compromisso acordado por muitos anos e de criar o filho longe de uma zona de conflitos. Por outro lado, a transição contínua entre duas casas pode reforçar a ansiedade da criança em relação a sua nova rotina.

Contudo, apesar da gravidade desses estudos, posteriormente ao se analisar os efeitos do divórcio na vida de adultos (25 anos após o divórcio), não se encontraram diferenças significativas entre os casos de guarda única e guarda conjunta. ${ }^{67}$ Enfim os autores concordam que a guarda conjunta como uma presunção legal, sem avaliar diversos critérios, é uma política desajustada e irrealista, devendo-se analisar tanto a realidade da criança como de ambos os pais, analisando individualmente caso a caso.

Conclui-se que a guarda conjunta é um esforço de ambos os pais em que a criança possa conviver harmoniosamente com eles após a separação, onde se comprometem a colaborar em sua educação com igualdade de direitos e deveres, e deve ser utilizado em certos casos específicos e nunca como uma regra geral, pois pode tornar a vida da criança mais complicada após o divórcio dos seus pais, que por si só já gera sofrimento e angústia. Não devendo ser aplicado em caso de violência doméstica e de imenso conflito entre os pais, pois gerará mais conflitos.

\footnotetext{
${ }^{67}$ WWLLERSTEIN, J/LEWIS, J;/BLAKESLEE, S., The Unexpected Legacy of Divorce, A 25 year Landmark Study, U.K., 2002, p. 167-175.
} 


\section{CONCLUSÃO}

A Lei da guarda compartilhada, tanto no Brasil como em Portugal segue a mesma tendência, pretendendo um amplo esquema de convivência entre pais e filhos, contato e uma melhor comunicação após a separação conjugal. Cuida-se do direito dos filhos de serem criados e educados por ambos os pais, que legalmente são responsáveis por eles. Deve-se destacar que esse processo é mundial no ocidente tendo como exemplos as alterações no Código Civil espanhol (arts.156, 159, 160), o Código de família de Cuba (ars.57 a 58), o Código Civil português (art.1905º), o Código Civil uruguaio (arts. 252, 257) e o Código Civil Francês (art. 373-2).

Predominava na nossa legislação pátria, antes da Lei 11.698/2008 a cultura da mãe ter a guarda unilateral, contrariando princípios como o da igualdade e da corresponsabilidade parental. Porém, seguindo o princípio de melhor interesse da criança, foi redefinido o modelo independente do sexo dos pais, pois agora se atribui a guarda a quem revele melhores condições de exercê-la, porém esta decisão não impede a convivência do outro pai na vida do filho. Igualmente, em Portugal, a mãe na sua maioria ficava com a criança, porém neste país quem tinha a guarda acumulava todas as obrigações em relação a criança, ou seja, diferente de nós que mesmo no caso de não se deter a guarda se mantém as obrigações em relação aos filhos, com direitos e deveres em relação ao filho.

A proposta da nova lei manter as funções já exercidas pelos pais, sem diminuir abruptamente a convivência da criança com um dos genitores, essa convivência deve ser fundada na cooperação dos pais para buscar um novo modelo de guarda mais democrática e tenta diminuir os traumas da separação.

Cabe ressaltar que, antes da vigência da lei quando se decidia pela guarda compartilhada, esta vinha na sua maioria somente através de acordo entre os pais e mais raramente ainda por determinação judicial. Com a nova 
lei, no nosso país, tem-se o diferencial no qual ao ocorrer ausência de consenso entre os pais, deve ser aplicada preferencialmente a guarda compartilhada pelo juiz como regra. Já em Portugal, a guarda compartilhada só é considerada pelo juiz quando existe acordo entre os pais nesse sentido, pois estes consideram que a guarda compartilhada entre casais em litigio provocaria mais problemas para o menor, além do mais não é aconselhada para crianças de tenra idade.

Mas, existe uma parte da doutrina e da jurisprudência na nossa legislação pátria que são contrárias a imposição da guarda compartilhada, especialmente aos casais que estão em conflito, pois a guarda obrigaria aos pais a conviver de uma forma frequente e deveriam deixar seus sentimentos pessoais em prol do filho, e muitas vezes isso leva um longo tempo, que exige ajuda de profissionais da área de psicologia e/ou psiquiatria.

Porém, não devemos deixar de ver os aspectos de que a lei procura romper com a cultura adversarial pela posse do filho, eliminando a ideia de que haverá ganhadores e perdedores numa luta pela guarda do filho, mostrando que o caminho a ser seguido é o do melhor bem estar da criança, e este caminho é o que traz a participação plena de pai e mãe na vida da criança, sem ter que necessariamente compartilhar dias da semana, em duas casas.

Enfim, existem diversos aspectos subjetivos que não devem ser perdido na decisão pela guarda compartilhada, que procura corrigir muitas injustiças com os pais que não detém a guarda, promovendo o melhor interesse do menor, que deve conviver com ambos os pais. 


\section{BIBLIOGRAFIA}

AIAS, José. Manual de derecho romano. [S.1.: s.n.], 20??.

BAPTISTA, Silvio Neves. Guarda Compartilhada. Recife: Bagaço, 2008.

BEVILÁQUA, Clóvis. Código Civil dos Estados Unidos do Brasil Comentado. v.2 Rio de Janeiro: Francisco Alves, 1937

BITENCOURT, E.M. Da guarda de Filhos. São Paulo: Leud, 1981, p.70-73.

BITTAR FILHO, Carlos Alberto. Pátrio Poder: regime jurídico pauta. Revista dos Tribunais, v. 676, 1992.

BRUNO, Denise Duarte. Direito de visita: direito de convivência. In: GROENINGA, Giselle Camara; PEREIRA, Rodrigo da Cunha (coords.) Direito de família e psicanálise. São Paulo: Imago, 2003.

CARBONNIER, Jean. Les Notion a Contenu Variable em Droit. Bruxeles: Ètudes publiéss par Chain Perelman et Raymond Vander Elst, 1984.

CUNHA GONÇALVES. Tratado de Direito Civil. V. VII, Coimbra, 1932.

DIAS, Maria Berenice. Manual de Direito das Famílias. 8. ed. Rio de Janeiro: Revista dos Tribunais, 2011. Disponível em <http://www.direitonet.com.br/artigos/exibir/4895/Guarda-compartilhadaluzes-e-sombras>. Acesso em: 09/11/2013.

DREYFUS. Cousenling the Divorced Father. Journal of Marriage and Family Therapy, n.5, 1979.

FACHIN, L.E. Estabelecimento da filiação e paternidade presumida. Porto Alegre: Sérgio Antônio Fabris, 1992.

GOMES, Júlio. A Mediação e o Divórcio. A Experiência Norte-Americana. Scientia Jurídica. Tomo XXXVIII, 1989.

GRIMALDI, Maria Rosa. Affidamento Congiunto e Alternato dela Prole tra Psicologia e Diritto. DFP, vol. XVIII, 1989.

GRISARD FILHO, Waldyr. Guarda Compartilhada: um novo modelo de responsabilidade parental. Rio de Janeiro: Editora Revistas dos Tribunais, 2013. 
GUY RAYMOND. De la realité du couple conjugal a la fiction de l' unité du couple parentale. Comentaire de l loi, no 87-570, juillet 1987 J.C.P, I, 3299.

JACK WESTMAN. Joint Custody from the Child's point of view, in Joit custody. A handbook for judges, lawyers and counselo rs. The Association of Family Courts. May 1979.

JOHNSTON, Janet R; LINE. Marsha; TSCHANN. Jeanne M. Ongoing Post divorce Conflict: Efects on Children of Joint Custod and Frequent Access. American Journey of Orthopsyquiatriy, v. 59, 1989.

LEITE, E. O. Famílias. Jornal of Law \& The Family, v. 8, n. 2, agosto de 1994.

MACCOBY, E.E.; MNOOKIN. R.H. Dividing the Child: Social and Legal Dilemamas of Custody. Cambridge. MA/London, Harvard University Press, 1992.

MARRACCINI, Eliane Michelini; MOTTA, Maria Antonieta Pisano. Guarda dos Filhos: Algumas diretrizes psicanalíticas. Revista dos Tribunais, v.716, p. 346-357

MASON, Mary Ann. Fron Father's Property to Chrildren Rights. The History of Chrildren Custody in the United States. New York: Columbia University Press, 1994.

MEIRA, S.A.B. A lei das XII Tábuas - fonte do Direito Público e Privado. $2^{\mathrm{a}}$ ed. Rio de Janeiro: Forense, 1961.

MOURA, Mário Aguiar. Guarda de filho menor. Ajuris, n.19, [??].

PATRICIA GROVE, Joint Custody. A Concept That has come of age but needs refiement. American Journal of Family Law, volume 1, nº 1 , Spring 1987.

PEREIRA, Lafayette. Direitos de família. Rio de Janeiro: Virgílio Maia, 1918

POLIKOFF, Nancy. Why Mothers are loosing. A Brief Analysis of Criteria Used in Child Costody Determinations. Womens Law Reporter, vol.7, $\mathrm{n}^{\circ} 3$, 1982

RAINER BALLOF. Gemeinsame elterliche Sorge als Regelfall? FamRZ, v. $90,2.2$

RIBEIRO, Maria Saldanha Pinto. O Divórcio e a Guarda Conjunta, Lisboa Centro Pai-Mãe-Criança. Associação Portuguesa de Mulheres Juristas, 1994. 
ROCHA, J.V.C.B. O Pátrio Poder: estudo teórico-pratico, Rio de Janeiro: Tupã, 1960.

ROSEMARY MCKINNON; JUDITH WALLERSTEIN. Joint custody and the prescooler childa. Behavior Scienses and The Law, vol 4, n² 1986.

SAYÃO, R. Pai e mãe podem pensar diferente na educação. Folha de São Paulo, Folha equilíbrio. Suplemento, 24 de junh. 2004, p.9.

SILVA.J.L.M. A família Substituta no Estatuto da Criança. São Paulo: Saraiva, 1995.

SOTTOMAYOR, Maria Clara. Exercício do poder Paternal relativamente à pessoa do filho após o divórcio ou a separação judicial de pessoas e bens. Universidade Católica Portuguesa. Portugal: Editora Porto, 1995

SOTTOMAYOR, Maria Clara. Regulação do Exercício do Poder Paternal nos Casos de Divórcio. 4 Ed. Coimbra: Almedina, 2008.

TEIXEIRA, Ana Carolina Brochado. Família, guarda e autoridade parental. São Paulo: RENOVAR, 2005.

TORRES, Anália. O Divórcio em Portugal, ditos e interditos: uma análise sociológica. Oeiras: Celta Editora, 1996. 